
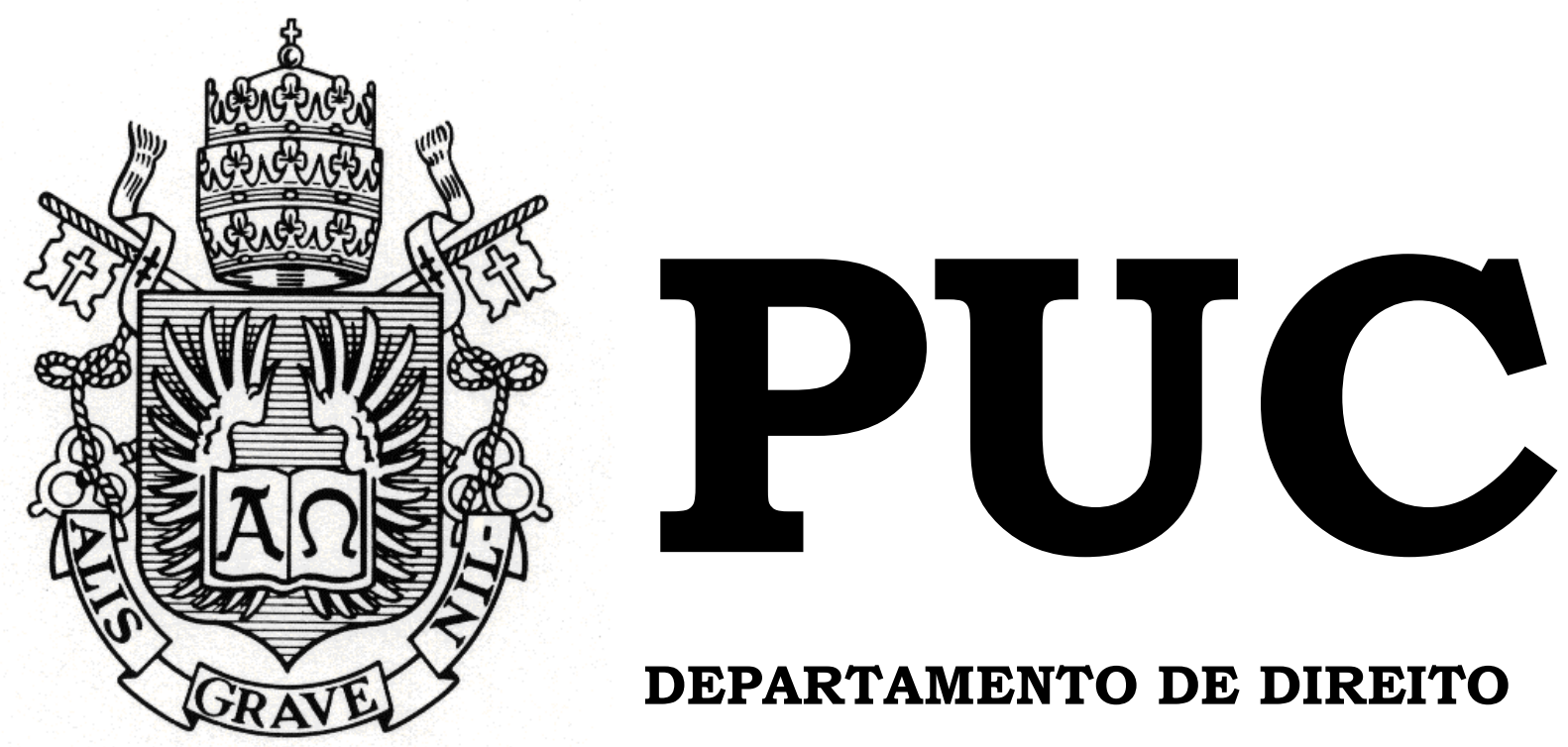

DEPARTAMENTO DE DIREITO

\title{
DOS CONTRATOS DE AFRETAMENTO MARÍTIMO E DE TRANSPORTE DE MERCADORIAS POR MAR
}

por

RENATA BARREIROS LABRUNA

ORIENTADOR: LAURO DA GAMA E SOUZA JÚNIOR 2011.1

PONTIFÍCIA UNIVERSIDADE CATÓLICA DO RIO DE JANEIRO RUA MARQUÊS DE SÃO VICENTE, 225 - CEP 22451-900 RIO DE JANEIRO - BRASIL 


\title{
DOS CONTRATOS DE AFRETAMENTO MARÍTIMO E DE TRANSPORTE DE MERCADORIAS POR MAR
}

\author{
por \\ RENATA BARREIROS LABRUNA
}

Monografia apresentada ao Departamento de Direito da Pontificia Universidade Católica do Rio de Janeiro (PUC-Rio) para a obtenção do Título de Bacharel em Direito.

Orientador: Lauro da Gama e Souza Júnior 
"Blackbird singing in the dead of night Take these broken wings and learn to fly All your life You were only waiting for this moment to arise"

(Paul McCartney) 
Dedico este trabalho ao meu avô materno José Guimarães Barreiros, o qual admiro pelo imenso amor à vida, à família e à navegação.

Ofereço, in memorian, à mina avó paterna Vilma Mansur Labruna, "Vinha", por todo amor e dedicação. 


\section{AGRADECIMENTOS}

Agradeço, primeiramente, à minha família, pelo apoio, em especial aos meus irmãos Antonio, Roberta, Maria e Rodrigo, por serem tudo na minha vida, bem como à minha "boadrasta" Renata e ao meu padrasto José Guilherme, por todo o carinho.

À minha mãe Ana Luiza, pelo exemplo de vida, apoio e amor incondicional.

Ao meu pai, Luiz, pela dedicação, amor à família, carinho e pelos ensinamentos na área de navegação, que foram de suma importância para a realização deste trabalho.

Agradeço, ainda, ao Mario, pelo companheirismo, força e amor em todos os momentos.

Aos meus amigos, pelos momentos de alegria, aos meus colegas de trabalho, com destaque ao meu chefe Lucas Leite Marques, pelos ensinamentos transmitidos e a todos aqueles que me ajudaram nesta jornada.

Finalmente, os meus sinceros agradecimentos ao mestre Lauro Gama, pela confiança, apoio e pelo conhecimento transmitido. 


\section{RESUMO}

LABRUNA, Renata Barreiros. Dos Contratos de Afretamento Marítimo e de Transporte Internacional de Mercadorias por Mar. Rio de Janeiro: PUC-RIO, 2011 62p. (Monografia - Departamento de Direito)

Diante do desenvolvimento da indústria naval e do aumento do comércio internacional surge a necessidade de maior aprofundamento acerca dos contratos de afretamento e de transporte por mar, tendo em vista que o Brasil ainda está muito atrasado no aspecto jurídico desta temática. $\mathrm{O}$ presente trabalho se subdivide em três grandes temas. Num primeiro momento, aborda-se a autonomia da vontade das partes em contratos internacionais, com uma exposição da questão da escolha da legislação a ser aplicada e da eleição de foro competente para dirimir eventuais litígios. Posteriormente, há a abordagem dos contratos de afretamento, adentrandose nas suas peculiaridades, tais como natureza jurídica, contrato padrão e suas cláusulas específicas, modalidades existentes, o regime de responsabilização das partes contratantes e formas de resolução. Finalmente, há o exame dos contratos de transporte internacional de mercadorias por mar, com destaque para o contrato padrão utilizado, as convenções internacionais sobre a questão, o regime de responsabilização das partes contratantes e a figura do N.V.O.C.C., cada vez mais comum no cenário da navegação internacional.

PALAVRAS-CHAVE: Direito; Marítimo; Afretamento; Transporte de Mercadorias. 


\section{SUMÁRIO}

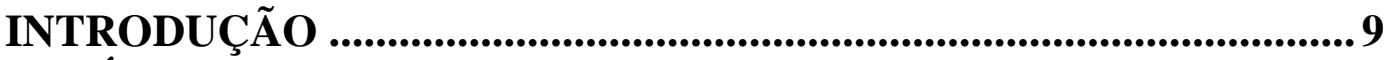

CAPÍTULO 1 - DA AUTONOMIA DA VONTADE DAS PARTES NOS CONTRATOS INTERNACIONAIS ........................................13

1.1 - Contratos Internacionais e da Autonomia da Vontade................. 13

1.2 - Legislação Aplicável ............................................................... 13

1.3. - Cláusula de Eleição de Foro Estrangeiro .................................... 16

CAPÍTULO 2 - CONTRATOS DE AFRETAMENTO MARÍTIMO 21

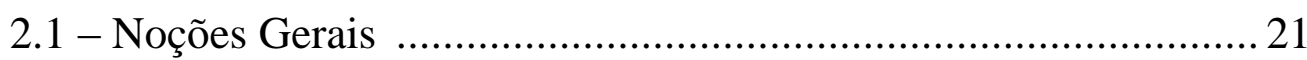

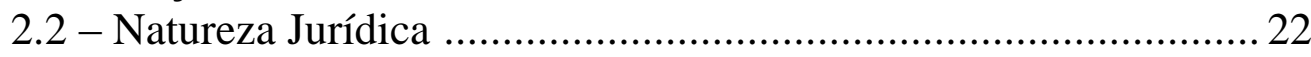

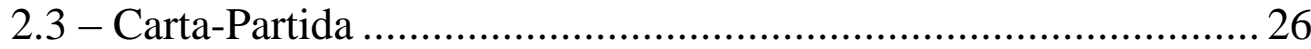

2.4 - Espécies de Afretamento ............................................................ 32

2.4.1 - Afretamento por Tempo ou a Prazo ................................. 33

2.4.2 - Afretamento a Casco $\mathrm{Nu}$................................................. 34

2.4.3 - Afretamento por Viagem.................................................36

2.4.4 - Do Afretamento Total e Parcial ....................................... 38

2.5 - Responsabilidade das Partes Contratantes ....................................39

2.6 - Resolução dos Contratos de Afretamento ................................... 41

CAPÍTULO 3 - CONTRATOS DE TRANSPORTE DE

MERCADORIAS POR MAR .......................................................43

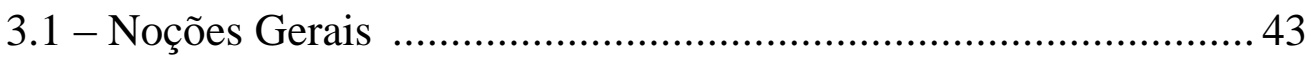

3.2 - Bill of Lading - Conhecimento de Embarque ………………...... 44

3.3 - Convenções Internacionais ....................................................... 46

3.4 - Responsabilidade das Partes Contratantes ................................... 49

3.5 - N.V.O.C.C. - Non Vessel Operator Common Carrier ................56

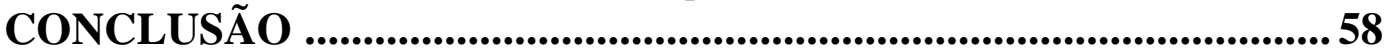

REFERÊNCIAS BIBLIOGRÁFICAS .................................................60

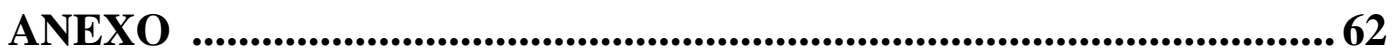




\section{LISTA DE TABELAS E ABREVIAÇÕES}

$\mathrm{BL}=$ Bill of Lading (Conhecimento de Embarque)

$\mathrm{CC}=$ Código Civil

$\mathrm{CPC}=$ Código de Processo Civil

$\mathrm{CP}=$ Carta-Partida

LIC = Lei de Introdução ao Código Civil

STJ = Superior Tribunal de Justiça 


\section{ANEXO DE FIGURAS}

Figura 1 - Modelo de Conhecimento de Embarque (BL) 


\section{INTRODUÇÃO}

\section{Apresentação do Tema}

A arte da navegação sempre exerceu grande fascínio ao homem, tendo sido elemento fundamental na evolução das sociedades ao longo da História e no desenvolvimento das relações comerciais. A utilização das embarcações para transporte de mercadorias e pessoas por mar foi fator fundamental para a evolução do comércio e exploração de novos mercados e, como o decorrer do tempo, tornou-se cada vez mais necessária a criação de institutos jurídicos voltados à regulamentação deste setor.

Eduardo de Avelar Lamy explica essa influência histórica na elaboração de uma ciência jurídica marítima:

"O surgimento de um ramo da ciência jurídica destinado a regular o transporte de coisas ou pessoas através das vias aquáticas foi conseqüência natural das conquistas históricas realizadas por diversas civilizações que se aventuraram pelos oceanos.

No ano de 1681, durante o reinado de Luís XIV, elaborou-se a primeira codificação do Direito Marítimo, compreendendo tanto o Direito Marítimo privado quanto o Direito Marítimo público, e que alcançou grande importância no continente europeu, influenciando os ordenamentos de vários países. "

O Código Comercial francês, conhecido como "Código Napoleão", dedicou o seu livro II ao Direito Marítimo, tendo exercido grande influência sobre o Código Comercial Brasileiro de 1850, que também disciplinava o Direito Marítimo na sua segunda parte. Estas regulações permaneceram no Código Civil de 2002, apesar do mesmo ter revogado a primeira parte do Código Comercial de 1850.

As regras do Direito Marítimo englobam os transportes lacustres e fluviais, bem como a navegação, o comércio marítimo, os contratos de transporte de bens e pessoas e a responsabilidade das partes integrantes dessas relações jurídicas. Percebe-se, portanto, a grande relevância do

\footnotetext{
${ }^{1}$ LAMY, Eduardo de Avelar. Contrato de Transporte Marítimo Internacional: Competência e Legislação Aplicável. In: JÚNIOR, Osvaldo Agrinpino Castro (Org.). Direito Marítimo Made in Brasil. São Paulo: Lex Editora S.A., 2007, p.97.
} 
direito para fins de comércio internacional, sendo de suma importância o seu estudo e divulgação. Ademais, a maior parte das relações comerciais de importação e exportação é concretizada através do transporte marítimo.

Diante do significativo crescimento das relações econômicas numa escala global, o transporte internacional de mercadorias tem ganhado cada vez mais força. Neste aspecto, merece atenção o transporte por mar, que representa, na atualidade, $90 \%$ do transporte total de mercadorias.

\section{Domínio A bso luto do Transporte Marítimo (milhões Ton)}

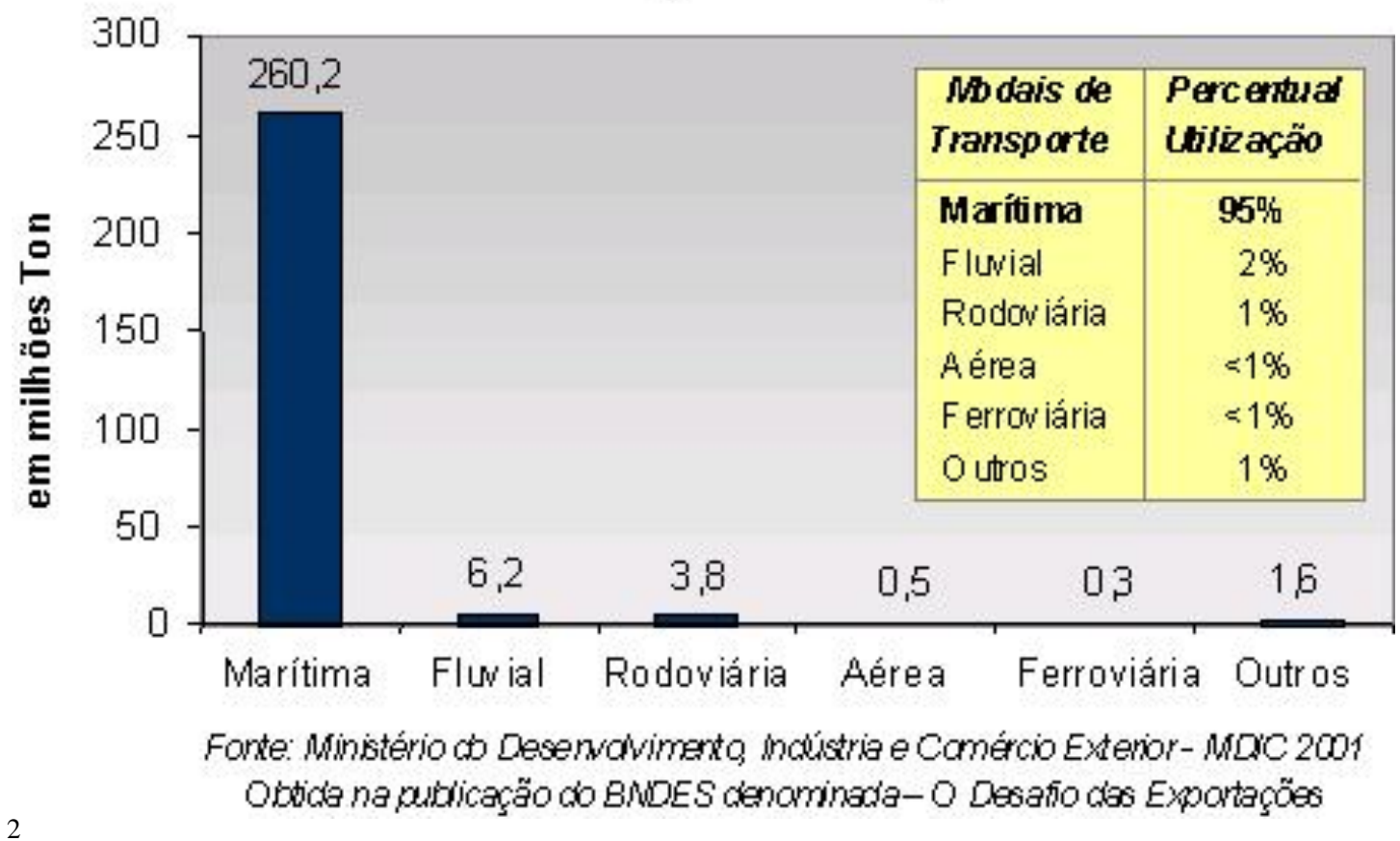

No cenário nacional a realidade não é diferente, a despeito da carência normativa na área de Direito Marítimo. A Constituição Federal reconhece o Direito Marítimo como um ramo autônomo da ciência jurídica pela Constituição Federal, em seu artigo 22, I:

“Art. 22. Compete privativamente à União legislar sobre:

I - direito civil, comercial, penal, processual, eleitoral, agrário, marítimo, aeronáutico, espacial e do trabalho.

\footnotetext{
${ }^{2}$ http://www.ilos.com.br/site/index.php?option=com content\&task=view\&id=710\&/temid=74
} 
Contudo, mesmo havendo o reconhecimento desta autonomia e, apesar da existência de normas infraconstitucionais sobre o tema, a legislação brasileira é defasada neste setor em relação ao cenário global. O Brasil deixou de ratificar importantes convenções sobre o tema e a legislação interna ainda carece de maior regulamentação, fato alarmante, tendo em vista o expressivo crescimento do setor marítimo no país, principalmente por força da descoberta do pré-sal.

Pelo fato do Brasil ainda estar defasado no aspecto jurídico do ramo da navegação e diante do expressivo crescimento dos negócios marítimos, verifica-se a urgente necessidade de maior exploração acadêmica desta matéria, de forma a impulsionar um conhecimento mais aprofundado por parte dos juristas, visando preparar profissionais para as situações que serão cada vez mais demandadas no país.

A presente obra, portanto, surgiu diante da constatação da imperiosa necessidade de aprofundamento na área Marítima. Pretende-se, neste sentido, esclarecer a dinâmica dos contratos de afretamento e transporte marítimo, essenciais na atualidade, de forma a incentivar o estudo, o desenvolvimento e a investigação científica deste ramo do Direito.

\section{Metodologia}

Para desenvolver este trabalho, de forma a esclarecer mais adequadamente os conceitos aqui abordados, baseou-se, primeiramente, nas pesquisas bibliográficas nacionais e internacionais sobre contratos de afretamento e de transporte marítimo. Houve, ainda, a análise da legislação aplicada e das Convenções Internacionais acerca da temática, de forma a esclarecer as divergências existentes, bem como delimitar o posicionamento internacional e do Brasil no âmbito da navegação.

\section{Plano de Trabalho}

A presente monografia se divide em três grandes partes, que, por sua vez, se subdividem, de forma a garantir a maior clareza e a organização da 
exposição da matéria. A primeira parte deste trabalho versa sobre questão fundamental em se tratando de contratos internacionais: a autonomia da vontade das partes, havendo a análise da sua incidência para efeitos de escolha da legislação a ser aplicada e da eleição de foro.

A segunda por sua vez, faz uma análise dos contratos de afretamento, abordando as noções gerais sobre o tema, a questão da autonomia da vontade em se tratando de contratos internacionais, relacionando-se com a escolha da legislação a ser aplicada e da eleição de foro, a natureza jurídica e o contrato padrão utilizado (carta-partida), as principais cláusulas, as espécies de afretamento, a questão da responsabilidade das partes contratantes e, finalmente, a resolução dos contratos de afretamento.

A terceira e última etapa da monografia, por sua vez, aborda o tema dos contratos de transporte internacional de mercadorias, havendo uma análise das noções gerais, do contrato padrão utilizado, denominado Conhecimento de Embarque (Bill of Lading), a questão da responsabilidade das partes contratantes e uma breve exposição da figura do N.V.O.C.C., que, como restará aqui demonstrado, é cada vez mais comum no cenário do comércio internacional. 


\section{CAPÍTULO 1 - DA AUTONOMIA DA VONTADE NOS CONTRATOS INTERNACIONAIS}

\subsection{Contratos Internacionais e Autonomia da Vontade}

Antes de adentrar nas questões referentes ao Direito Marítimo propriamente dito, cumpre analisar brevemente à questão do princípio da autonomia da vontade no âmbito da contratação internacional, de forma a garantir uma compreensão mais aprofundada da temática.

O elemento "estraneidade" é o fator caracterizador do contrato internacional, e por estraneidade entende-se qualquer elemento que conecte mais de um ordenamento jurídico. $\mathrm{Na}$ formação dos contratos internacionais as partes convencionam a norma a ser aplicada, além de elegerem o foro para a dissolução de eventuais controvérsias.

A priori as partes contratantes podem acordar livremente acerca da legislação aplicável e da competência jurisdicional. Contudo, tal princípio encontra limitações nas leis imperativas e de ordem pública de determinados Estados, como é o caso do Brasil.

\subsection{Legislação Aplicável}

É evidente que o Direito Marítimo tem sido alvo de tentativas de sistematização e uniformização da legislação aplicável, de forma a uniformizar tal disciplina. Não obstante os grandes esforços neste sentido de unificar a legislação no ramo do Direito Marítimo, na prática verificamse grandes dificuldades na elaboração e cumprimento dos negócios marítimos, permanecendo a problemática do conflito de leis. Ressalte-se que os contratos não são regidos tão-somente pelas normas codificadas, havendo, ainda, a incidência dos acordos internacionais e dos costumes dos portos. 
A posição brasileira no que tange a escolha da norma a ser aplicada em se tratando de contratos internacionais está pautada no artigo $9^{\circ}$ da LICC, o qual estabelece, in verbis:

\begin{abstract}
"Art. 90. Para qualificar e reger as obrigações, aplicar-se-á a lei do país em que se constituírem.

$\S 1^{\circ}$. Destinando-se a obrigação a ser executada no Brasil e dependendo de forma essencial, será esta observada, admitidas as peculiaridades da lei estrangeira quanto aos requisitos extrínsecos do ato.

$\S 2^{\circ}$. A obrigação resultante do contrato reputa-se constituída no lugar em que residir o proponente. “
\end{abstract}

A simples leitura deste dispositivo indica que o país adota a regra de conexão da lei do local da celebração do contrato, ou seja, eventuais litígios decorrentes de uma negociação internacional deverão ser pautados pela lei do local o qual foi celebrado. Num primeiro momento, como leciona Nadia de Araujo, a regra da lei do local de celebração do contrato era plausível, expondo ainda a dinâmica ocorrida nos contratos de transporte internacional:

"Nos contratos de transporte internacional os acertos celebravam-se no porto, $e$ o armador, mais do que um transportador especializado, tinha o papel de mercador, assumindo todos os riscos da transação dali para a frente. Era comum os comerciantes virem ao porto oferecer-lhe mercadorias e muitos contratos eram ali celebrados". 3

Faz-se necessário destacar o disposto pelo artigo 628 do Código Comercial acerca dos contratos exequíveis no Brasil envolvendo embarcações estrangeiras, artigo este pautado na regra do local da execução do contrato: "O contrato de fretamento de um navio estrangeiro exeqüível no Brasil, há de ser determinado e julgado pelas regras estabelecidas neste Código, quer tenha sido ajustado dentro do Império, quer em país estrangeiro".

Outra regra de definição da legislação adotada, conforme dispõe o $\$ 1^{\circ}$ acima transcrito, é a que determina que a norma a ser aplicada é aquela do local onde será executado o contrato internacional. Nadia de Araujo

\footnotetext{
${ }^{3}$ ARAUJO, Nadia de. Direito Internacional Privado. Teoria e Prática Brasileira. Rio de Janeiro: Renovar, 2008. p. 367.
} 
expõe, contudo, que estas duas formas de delimitação da norma a ser aplicada perderam força diante do desenvolvimento das relações comerciais e das comunicações no mundo, o que acabou por fortalecer o princípio da autonomia da vontade, ressalvando, entretanto, que:

"Embora a autonomia da vontade tenha sido aceita mundialmente, as regras consubstanciadas pela escola italiana (lei do local da celebração) ainda têm grande utilização nos países de tradição romanp-germânica da América Latina”.

O artigo 13 da LICC de 1916 previa que: "Regulará, salvo disposição em contrário, quanto à substância e aos efeitos da obrigação, a lei do local onde forem contraídas". É sabido, ainda, que o artigo $9^{\circ}$ da atual LICC pautou-se no artigo 13 da LICC de 1916, tendo suprido, tãosomente, a expressão "salvo disposição em contrário".

Por este fato, surge uma grande divergência doutrinária acerca da validade ou não da autonomia da vontade no cenário internacional, conforme perfeitamente apontado por Nadia de Araujo:

"Com as normas da Lei de Introdução ao Código Civil, de 1942, nasceu uma nova discussão na doutrina, sobre a exclusão ou não do princípio, em face da supressão da expressão 'salvo disposição em contrário', que antes a permitia. A polêmica perdurou, pois enquanto muitos acharam que isso significaria a vontade do legislador em eliminá-la, outros entenderam que a simples supressão da expressão não poderia eliminar um princípio jurídico anteriormente aceito". 5

Além disso, o artigo 17 da LICC, por sua vez, com o intuito de defender a soberania nacional, estabelece que: "As leis, atos e sentenças de outro país, bem como quaisquer declarações de vontade, não terão eficácia no Brasil, quando ofenderem a soberania nacional, a ordem pública e os bons costumes".

Importante destacar que o Brasil não ratificou as convenções internacionais referentes ao tema, convenções estas que normalmente são a base destes contratos. Desta forma, os negociantes brasileiros não têm

\footnotetext{
${ }^{4}$ ARAUJO, Nadia de. Direito Internacional Privado. Teoria e Prática Brasileira. Rio de Janeiro: Renovar, 2008. p. 367.

${ }^{5}$ Ibid. p. 374.
} 
maior liberdade de escolha da legislação aplicável ou da competência. Neste sentido leciona Eduardo de Avelar Lamy:

"Em princípio, dever-se-ia escolher a lei ou as leis em que se funda o contrato internacional através da inserção de cláusula específica no referido instrumento. No entanto, especialmente nos contratos de transporte marítimo internacional não tem existido tal escolha para os negociantes brasileiros, uma vez que as bases legais em que estes usualmente se fundam são convenções internacionais que fazem parte do ordenamento interno da maioria dos países Europeus e dos Estados Unidos, que as ratificaram, mas que não fazem parte do nosso ordenamento, vez que não foram ratificadas pelo Brasil. "6

Desta forma, verifica-se que não há um consenso acerca da incidência ou não da autonomia da vontade da partes na contratação em âmbito internacional, o que acaba por colocar o Brasil em uma posição de desvantagem comercial, não estando em consonância com a tendência internacional.

Finalmente, apenas à título de curiosidade, destaca-se que os contratantes internacionais têm dado preferência à lei inglesa nos contratos de afretamento e transporte no mundo inteiro, uma vez que esta é uma das mais vastas e bem delimitadas no ramo do Direito Marítimo.

\subsection{Cláusula de Eleição de Foro Estrangeiro}

Nadia de Araujo inicia sua abordagem acerca da cláusula de eleição de foro no âmbito internacional fazendo uma distinção primordial: " $A$ cláusula de eleição de foro não se confunde com a da lei aplicável”.'

Tal diferenciação é fundamental, uma vez que a eleição de foro estrangeiro não está vinculada à lei aplicável, podendo haver a situação de julgamento em determinado local com a aplicação da lei de outro. No geral, as partes podem garantir que o sistema normativo escolhido no contrato será de fato aplicado através da eleição de um foro no qual haja o entendimento no sentido de reconhecer amplamente a autonomia da

\footnotetext{
${ }^{6}$ LAMY, Eduardo de Avelar. Contrato de Transporte Marítimo Internacional: Competência e Legislação Aplicável. In: JÚNIOR, Osvaldo Agrinpino Castro (Org.). Direito Marítimo Made in Brasil. São Paulo: Lex Editora S.A., 2007, p.100.

7 ARAUJO, Nadia de. Direito Internacional Privado. Teoria e Prática Brasileira. Rio de Janeiro: Renovar, 2008. p. 381.
} 
vontade das partes. No caso do Brasil, contudo, afigura-se uma incerteza jurídica, em virtude da ausência de consenso neste âmbito.

No cenário nacional, destaca-se, primeiramente, a súmula 335 do Supremo Tribunal Federal, que dispõe: “É válida a cláusula de eleição do foro para os processos oriundos do contrato". A despeito de parte da doutrina defender que esta súmula é aplicada aos contratos internacionais, há uma corrente mais antiquada que se posiciona no sentido inverso, não estando em consonância com a tendência mundial.

Em se tratando de competência exclusiva, os Tribunais têm perpetuado a orientação de que a decisão proferida foro estrangeiro não terá eficácia no Brasil.

Nas hipóteses de concorrência competente, há uma grande divergência. A doutrina tem se posicionado no sentido de apoiar a validade da cláusula de eleição de foro estrangeiro, de forma a impulsionar as relações comerciais travadas pelo Brasil no cenário internacional. No sentindo contrário, contudo, caminha a jurisprudência, determinando a competência brasileira nas situações em que há cláusula de eleição de foro estrangeiro nas hipóteses previstas pelo artigo 88 do Código de Processo Civil, que estabelece in verbis:

“Art. 88. É competente a autoridade judiciária brasileira quando:

I - o réu, qualquer que seja a sua nacionalidade, estiver domiciliado no Brasil;

II - no Brasil tiver de ser cumprida a obrigação;

III - a ação se originar de fato ocorrido ou de ato praticado no Brasil.

Parágrafo único. Para o fim do disposto no I, reputa-se domiciliada no Brasil a pessoa jurídica estrangeira que aqui tiver agência, filial ou sucursal”.

Nadia de Araujo esclarece que:

"A cláusula de eleição de foro, perfeitamente válida e permitida pelo direito brasileiro, teria o mero efeito de ser uma obrigação de fazer, sem poder, no entanto, dar às partes a segurança desejada de que somente no foro estrangeiro seria julgada a causa. Se a ação for proposta no Brasil, ainda que a cláusula pactuada remeta a causa a outro país, é provável que o juiz brasileiro se julgue competente". ${ }^{8}$

\footnotetext{
${ }^{8}$ ARAUJO, Nadia de. Direito Internacional Privado. Teoria e Prática Brasileira. Rio de Janeiro: Renovar, 2008. p. 384.
} 
A autora destaca, ainda, o precedente do STJ, abaixo transcrito, de forma a ilustrar a atual orientação neste aspecto ${ }^{9}$ :

COMPETÊNCIA INTERNACIONAL. CONTRATO DE CONVERSÃO DE NAVIO PETROLEIRO EM UNIDADE FLUTUANTE. GARANTIA REPRESENTADA OIR 'PERFORMANCE BOND'EMITIDO POR EMPRESAS ESTRANGEIRAS. CARÁTER ACESSÓRIO DESTE ÚLTIMO. JURISDIÇÃO DO TRIBUNAL BRASILEIRO EM FACE DA DENOMINADA COMPETÊNCIA CONCORRENTE (ART. 88, INC. II, DO CPC).

(...)

-Caso em que empresas as garantes se sujeitam à jurisdição brasileira, nos termos do disposto no art. 88, inc. II, do CPC, pois no Brasil é que deveria ser cumprida a obrigação principal. Competência internacional concorrente da autoridade judiciária brasileira, que não é suscetivel de ser arredada pela vontade das partes.

-À jurisdição brasileira é indiferente que se tenha ajuizado ação em país estrangeiro, que seja idêntica a outra que aqui tramite. Incidência na espécies do art. 90 do CPC.

Recurso Especial não conhecido, prejudicada a medida cauterlar.

(REsp 251.438/RJ. Minstro Barros Monteiro. Quarta Turma. 08/08/2000).

Na mesma linha se posiciona o acórdão abaixo do STJ, afirmando que a competência internacional concorrente não afasta a competência da autoridade brasileira:

"PROCESSO CIVIL. CLÁUSULA DE ELEIÇÃO DE FORO. COMPETÊNCIA INTERNACIONAL. ART. 88 DO CPC. NOTAS TAQUIGRÁFICAS. INTIMAÇÃO.PRECLUSÃO. EMBARGOS DE DECLARAÇÃO. COLHIMENTO, SEM EFEITOS MODIFICATIVOS.

1. A cláusula de eleição de foro estrangeiro não afasta a competência internacional concorrente da autoridade brasileira, nas hipóteses em que a obrigação deva ser cumprida no Brasil (art. 88, II, do CPC). Precedentes.(...)”

(Edcl nos Edcl no REsp 1159796/PE. Ministra Nancy Andrighi. Terceira Turma. 25/03/2011).

$\mathrm{O}$ artigo 12 da LICC determina que: "É competente a autoridade judiciária brasileira, quando for o réu domiciliado no Brasil ou aqui tiver de ser cumprida a obrigação".

Ressalte-se, ainda, o artigo 90 do Código de Processo Civil, que prevê: "A ação intentada perante tribunal estrangeiro não induz litispendência, nem obsta a que a autoridade judiciária brasileira conheça da mesma causa e das que Ihe são conexas”.

\footnotetext{
${ }^{9}$ ARAUJO, Nadia de. Direito Internacional Privado. Teoria e Prática Brasileira. Rio de Janeiro: Renovar, 2008. p. 387.
} 
No sentindo contrário verifica-se ainda uma corrente jurisprudencial, com menor força, que defende a eficácia da cláusula de eleição de foro estrangeiro nas situações em que há plena liberdade contratual, o que não se verifica nos contratos de adesão. Este é o entendimento de Eliane Martins: "Evidencia-se que, como regra, tem se consolidado o entendimento jurisprudencial no sentido de a cláusula de eleição de foro ter eficácia plena quando há inteira liberdade de contratar." ${ }^{10}$

Para ilustrar tal posicionamento, cumpre transcrever o precedente abaixo:

"PROCESSO CIVIL. CONTRATO DE ADESÃO. FORO DE ELEIÇÃO. PREVALENCIA DE REGRA GERAL DE COMPETENCIA (ART. 100, IV, "B", CPC). RECURSO NÃO CONHECIDO.

I - A clausula de eleição de foro inserida em contrato de adesão e, em principio, valida e eficaz, salvo:

A) se, no momento da celebração, a parte aderente não dispunha de Intelecção suficiente para compreender o sentido e as conseqüencias da estipulação contratual;

B) se da prevalência de tal estipulação resultar inviabilidade ou especial dificuldade de acesso ao judiciário;

C) se se tratar de contrato de obrigatória adesão, assim entendido o que tenha por objeto produto ou serviço fornecido com exclusividade por determinada empresa.

II - Reconhecida qualquer dessas circunstancias excepcionais, a definição da competencia se impõe seja procedida segundo as regras gerais estabelecidas no diploma processual (no caso, art. 100, iv, "b", CPC)".

(STJ, REsp n. 46.544/RS; $4^{\mathrm{a}}$ T. Ministro Salvio de Figueiredo Teixeira, RE n. 1994/0010030-2, j. 10.05.1994)

Pode-se, dizer, portanto, não haver certeza quanto à aplicação da cláusula de eleição de foro estrangeiro no Brasil, sendo mais seguro optar pela cláusula compromissória arbitral, uma vez que a arbitragem confere maior segurança jurídica na execução do que fora pactuado nos contratos internacionais, além de evitar a incidência da problemática oriunda dos conflitos de competência e de legislação aplicável. Ademais, a arbitragem oferece as vantagens usuais, tais como sigilo, celeridade e maior

\footnotetext{
${ }^{10}$ MARTINS, Eliane M. Octaviano. Curso de Direito Marítimo Vol. II. Barueri, São Paulo: Manole, 2008, p.87.
} 
especialidade, uma vez que os árbitros são escolhidos entre conhecedores do tema em litígio.

No cenário global, destaca-se que Alemanha, França, Holanda e Dinamarca reconhecem plenamente a autonomia da vontade das partes, podendo haver, inclusive, a escolha de uma terceira legislação, neutra na relação contratual. Inglaterra e Estado Unidos são, em tese, flexíveis, o que não se verifica na prática, tendo em vista que não tem se admitido a incidência dessa liberdade contratual nos negócios concluídos em território nacional. Por último, países como Austrália, Nova Zelândia, Bélgica, Itália e Egito, não reconhecem tal princípio.

Após esta breve análise sobre à autonomia da vontade das partes no âmbito internacional, adentra-se na exposição dos contratos do ramo do Direito Marítimo. 


\section{CAPÍTULO 2 - DOS CONTRATOS DE AFRETAMENTO MARÍTIMO}

\subsection{Noções Gerais}

$\mathrm{O}$ contrato de afretamento é aquele no qual o fretador coloca à disposição do afretador a utilização de um navio, ou parte deste, para navegação marítima, mediante uma contraprestação pecuniária denominada frete, também chamada de hire. Fretar significa ceder o navio (to charter), enquanto afretar significa receber o navio. Desta forma, os contratos de afretamento também são chamados de contrato de fretamento. Permite a utilização de navios mercantis, tanto para exploração de atividades náuticas, operação e controle do mesmo, quanto para o transporte de mercadorias e pessoas por mar, adotando o navio posição de objeto essencial para o cumprimento destes negócios jurídicos.

Os contratos de utilização de embarcações se subdividem em diversas espécies, dentre elas os contratos de afretamento e os contratos de transporte de mercadorias e de pessoas. Cumpre destacar neste aspecto a divergência existente quanto à natureza jurídica dos contratos de afretamento, os quais, como será defendido posteriormente, não se confundem com os contratos de transporte, ao contrário do sustentado por parte da doutrina.

Trata-se de uma relação jurídica no qual figura de um lado o fretador (owner, disponent), papel que será desempenhada pelo armador (podendo ser o proprietário do navio), e do outro o afretador (charterer), que receberá o navio para utilização e exploração.

Para maiores esclarecimentos, deve-se destacar que a pessoa do armador não se confunde, necessariamente, com a pessoa do proprietário do navio. O proprietário é aquele em nome de quem é inscrita a embarcação, é aquele que possui o direito sobre o navio. $\mathrm{O}$ armador, por sua vez, é quem efetua a armação do navio, ou seja, é o responsável por preparar a 
embarcação para uma expedição marítima, podendo ser pessoa física ou jurídica.

Eliane Martins apresenta a questão de forma brilhante:

"O armador, em seu nome e sob a sua responsabilidade, apresta a embarcação com fins comerciais, pondo-a ou não a navegar por sua conta. Evidencia-se, portanto, que o armador consagra-se o empresário da navegação marítima. Destarte, na acepção jurídica, o armador providencia a armação do navio e também o explora comercialmente e, via de conseqüência, assume as obrigações empresariais advindas da exploração econômica do navio". ${ }^{11}$

Destaca-se, ainda, a figura do corretor de navios cargo broker, que exerce a função de agente comercial, sendo cada vez mais comum no cenário marítimo. Trata-se de um intermediário entre fretadores e afretadores, especializado em afretamentos marítimos, que tem a função essencial de prestar serviços tais como reserva de praça e celebração de contratos de afretamento.

Os contratos de afretamento/fretamento são formalizados pela elaboração da carta partida (charter party), espécie contratual que será analisada mais adiante. Dependendo da modalidade de afretamento poderá haver a emissão do Conhecimento de Embarque (Bill of Ladding - BL).

\subsection{Natureza Jurídica dos Contratos de Afretamento}

A natureza jurídica dos contratos de afretamento constitui matéria de grande polêmica entre os juristas da área, em especial no que tange o transporte internacional de mercadorias. Tal divergência é ainda influenciada pela ausência de legislação própria sobre a temática no cenário nacional. $\mathrm{O}$ afretamento está previsto no Título VI do Código Civil e na Lei 9.432/97, que dispõe sobre a ordenação do transporte aquaviário, lei está que está limitada, tão somente, à conceituação dos institutos, abstendo-se da

\footnotetext{
${ }^{11}$ MARTINS, Eliane M. Octaviano. Curso de Direito Marítimo Vol. II. Barueri, São Paulo: Manole, 2008, p.150.
} 
devida regulação. O Código Comercial, por sua vez, faz breves menções da matéria, sem adentrar de fato na temática.

Ademais, como mencionado anteriormente, as convenções internacionais que versam sobre o tema deixaram de ser ratificadas pelo Brasil, não fazendo parte, portanto, do ordenamento jurídico interno. Desta forma, no âmbito do Direito Marítimo, a Lei de Introdução ao Código Civil não reflete a tendência internacional, o que gera grande retrocesso ao país, não havendo uma regulamentação precisa e objetiva quanto aos institutos do Direito Marítimo.

Por conseguinte, há uma grande divergência quanto à natureza e abrangência dos contratos de afretamento, destacando quatro correntes doutrinárias. A primeira entende que o contrato de transporte marítimo se confunde com o contrato de afretamento, que é interpretado no sentido lato sensu, não havendo diferença entre os dois tipos de contrato, como leciona Eliane Martins:

"A primeira corrente doutrinária, defende o enquadramento do contrato de transporte como contrato de fretamento. Destarte, para tais juristas, em sentido lato sensu, inexiste diferenciação de enquadramento dos contratos de transporte de utilização do navio no tráfico marítimo de transporte e de fretamento.

Tal enquadramento é particularmente comum na doutrina brasileira e decorre da própria insuficiência da moldura legal. Atende-se a redação dos arts. 566 a 628 do Código Comercial, anteriormente suscitados, que provocam, per se, equívocos de interpretação e enquadramento jurídico. ",12

A segunda corrente, por sua vez, não diferencia contrato de transporte de contrato de afretamento, aproximando todas as demais formas de afretamento à figura da locação. Esta corrente entende que quando o navio é cedido sem a obrigação de transportar mercadorias ou pessoas, não há que se falar em afretamento, havendo, na realidade, a locação do navio. Tal posicionamento é defendido por Carla Adriana Comitre Gibertoni, como segue no trecho transcrito:

\footnotetext{
${ }^{12}$ MARTINS, Eliane M. Octaviano. Curso de Direito Marítimo Vol. II. Barueri, São Paulo: Manole, 2008, p.141.
} 
"Em direito maritimo, fretamento é um contrato pelo qual o armador ou proprietário de um navio mercante se obriga, mediante o pagamento de frete, a transportar mercadorias de um porto a outro determinado. Trata-se então, de um contrato que diz respeito a locação do navio, prestação de serviços e transporte, sendo este um elemento essencial.

Se o navio é cedido sem a obrigação de transporte, como é o caso de um contrato a prazo ou a casco nu, não haverá fretamento, mas sim locação do navio. Distingue-se, pois, o fretamento, um contrato peculiar regulado pelo Código Comercial, dos demais contratos que são equiparados à locação de bens móveis, fixada no direito comum.

No entanto, trataremos aqui, da mesma forma como o direito internacional trata este tipo de contrato na prática, ou seja, entende-se por fretamento a ação ou efeito de ceder um navio a frete, sob qualquer de suas formas de utilização: por viagem, a prazo ou a casco $\mathrm{nu}$. ",l3

Repare, portanto, que apesar de defender a tese de que afretamento e contrato de transporte de mercadorias se confundem, havendo, ainda, a figura dos contratos de locação para as demais formas de exploração do navio, a autora reconhece que no direito internacional o entendimento é diverso, uma vez que o contrato de afretamento pode se dar em outras formas de utilização do navio. Tal posicionamento faz parte da quarta corrente, que será aqui defendida.

A terceira corrente defende basicamente que cada forma de afretamento possui uma natureza jurídica própria - os contratos de afretamento a casco nu, por exemplo, teriam natureza jurídica de locação, enquanto os afretamentos do tipo por tempo (time charter) teriam a natureza de prestação de serviços. Por sua vez, o tipo por viagem (voyage charter) seria um contrato de transporte.

O quarto entendimento, ora defendido, sustenta a interpretação sui generis do contrato de afretamento, não se confundindo com o contrato de transporte. O contrato de afretamento é aquele no qual o fretante coloca à disposição a navegabilidade do navio, não havendo, necessariamente, a obrigação de transportar bem ou pessoas. Já no contrato de transporte, há a

\footnotetext{
${ }^{13}$ GIBERTONI, Carla Adriana Comitre. Teoria e Prática do Direito Marítimo. Rio de Janeiro: Renovar, 2005, p. 173.
} 
obrigação necessária de transladar e entregar determinado bem do porto de origem ao porto de destino.

Conforme ensina Eliane Martins ${ }^{14}$, a diferença entre esses dois contratos reside no objeto essencial de cada um. $\mathrm{O}$ contrato de transporte tem como objeto o transporte de mercadorias de um porto a outro se distingue do contrato de afretamento uma vez que este último tem como objeto a disponibilidade da embarcação para a exploração das suas funções, e não o transporte propriamente dito. Contudo, o contrato de afretamento é comumente firmado com a finalidade de transportar, motivo pelo qual parte da doutrina entende que ambos se confundem o que não é verdade.

Um exemplo de afretamento não voltado para o transporte ocorre com o chamado supply vessel, que é um navio afretado para auxiliar as plataformas na exploração de petróleo e gás natural.

Verifica-se a existência de elementos semelhantes entre o contrato de afretamento e os contratos de transporte, locação e de prestação de serviços, mas não se pode confundir os mesmos. Nos contratos de afretamento há a individualização de um navio específico, contrata-se para a utilização de embarcação determinada, de forma a explorá-la para diversas atividades. No contrato de transporte marítimo, por outro lado, não há a especificação do navio a ser utilizado, havendo apenas um contrato de transporte por água e a obrigação de entregar a mercadoria no porto de destino acordado.

A diferença entre ambos os tipos de contrato deve ser analisada através da delimitação do elemento fundamental de cada um. Em outras palavras, o elemento fundamental do contrato de transporte é o transporte marítimo de mercadorias do porto de embarque ao porto de destino, previamente pactuados. O contrato de afretamento, por sua vez, tem como objeto essencial a utilização do navio, a exploração comercial da embarcação, o que pode incluir a modalidade transporte marítimo. Ou seja,

\footnotetext{
${ }^{14}$ MARTINS, Eliane M. Octaviano. Curso de Direito Marítimo Vol. II. Barueri, São Paulo: Manole, 2008, p.144.
} 
pode-se dizer que, como forma de utilização do navio, o transporte marítimo é uma modalidade de contrato de afretamento, que prevê ainda outras espécies de exploração de embarcações.

Eliane Martins esclarece bem a polêmica:

"Com efeito, o contrato de fretamento contempla apenas em segundo plano, $e$ não como conseqüência obrigatória, o transporte. Efetivamente, o contrato de fretamento permite aos empresários da navegação que não têm navios disponíveis obter no mercado não regular os navios apropriados aos seus propósitos comerciais, sejam estes de realizar o transporte de cargas próprias ou de terceiros". ${ }^{15}$

Outra diferença relevante entre estas duas figuras está no instrumento contratual utilizado. O contrato de afretamento se dá através do chamado carta-partida, em que há uma liberdade na negociação e da autonomia da vontade, aproximando-se dos contratos paritários. O contrato de transporte, por outro lado, resta evidenciado pelo chamado Conhecimento Marítimo ou Conhecimento de Embarque (Bill of Lading), que se assemelha a um contrato de adesão, com cláusulas pré-estabelecidas, o que será, mais adiante, demonstrado.

\subsection{Carta-Partida}

Os contratos de afretamento são formalizados por escrito, o que, no geral, se dá através de um contrato padrão chamado de carta-partida (charter party) ou carta de afretamento. A origem da expressão cartapartida deriva do latim medieval charta partita. Na Idade Média os contratos eram redigidos em papel que era rasgado ao meio, cabendo uma metade ao afretador e a outra ao fretador. Posteriormente, havia a comparação, a justaposição de ambas as metades, de forma a averiguar e comprovar a autenticidade do documento.

\footnotetext{
${ }^{15}$ MARTINS, Eliane M. Octaviano. Curso de Direito Marítimo Vol. II. Barueri, São Paulo: Manole, 2008, p.144-142.
} 
A carta-partida, no geral, é formalizada através de contratos standards, mas, ao contrário do conhecimento de embarque, não se assemelha aos contratos de adesão, uma vez que pode haver a inclusão de cláusulas adicionais, que serão anexadas ao contrato-padrão, formando um adendo conhecido como rider.

$\mathrm{Na}$ formação dos contratos tem-se, num primeiro momento a emissão de um documento chamado RECAP (recapitulação), no qual há a descrição de todos os termos do contrato padrão que foram preenchidos ou alterados, bem como a aceitação das cláusulas adicionais (rider). $\mathrm{Na}$ prática, muitas vezes não há a assinatura do contrato final, uma vez que após a aceitação do RECAP entende-se não haver necessidade desta formalização.

No que tange a estrutura contratual, cumpre demonstrar que, apesar de existir uma série de cláusulas variáveis de acordo com as peculiaridades do caso concreto, cláusulas estas que serão demonstradas mais adiante, há um padrão seguido nas cartas-partidas. Num primeiro momento há a identificação das partes, bem como a indicação das características específicas do navio, individualizando-o. Apontam-se, ainda, os portos de embarque e desembarque e as taxas incidentes, bem como a legislação aplicável e o foro competente. Neste tocante, ressalta-se que nos contratos padrão há a inclusão de cláusulas compromissórias de arbitragem.

No direito brasileiro, o artigo 567 do Código Comercial indica os elementos fundamentais que compõe esta espécie contratual:

\footnotetext{
"Art. 567 - A carta-partida deve enunciar:

1 - o nome do capitão e o do navio, o porte deste, a nação a que pertence, e o porto do seu registro (artigo $n^{o}$. 460);

2 - o nome do fretador e o do afretador, e seus respectivos domicílios; se o fretamento for por conta de terceiro deverá também declarar-se o seu nome e domicílio;

3 - a designação da viagem, se é redonda ou ao mês, para uma ou mais viagens, e se estas são de ida e volta ou somente para ida ou volta, e finalmente se a embarcação se freta no todo ou em parte;
} 
4 - o gênero e quantidade da carga que o navio deve receber, designada por toneladas, $n^{o}$ s, peso ou volume, e por conta de quem a mesma será conduzida para bordo, e deste para terra;

5 - o tempo da carga e descarga, portos de escala quando a haja, as estadias e sobre estadias ou demoras, e a forma por que estas se hão de vencer e contar; 6 - o preço do frete, quanto há de pagar-se de primagem ou gratificação, e de estadias e sobre estadias, e a forma, tempo e lugar do pagamento;

7 - se há lugares reservados no navio, além dos necessários para uso e acomodação do pessoal e material do serviço da embarcação;

8 - todas as mais estipulações em que as partes se acordarem."

Dentre as cláusulas constantes da carta-partida, destaca-se, na presente obra, as mais relevantes, que são utilizadas independente da modalidade de carta-partida utilizada.

A cláusula paramount, ou paramount clause, é tida como a principal cláusula existente na carta-partida, sendo aquela que indica a lei aplicável. Nos contratos de afretamento elege-se, no geral, a legislação inglesa, conforme previamente mencionado. Neste âmbito, importante trazer uma especificidade do direito brasileiro, que, no artigo $9^{\circ}$ da Lei de Introdução ao Código Civil, que estabelece que a lei a ser aplicada é a do país no qual foi celebrado o contrato, sendo irrelevante a disposição contratual neste sentido ou a omissão do mesmo.

Verifica-se que a cláusula paramount, pode estabelecer o chamado dépeçage, que nada mais é do que o fracionamento do contrato, uma vez que haverá a incidência de diversos regimes jurídicos distintos, que variam de acordo com a parte do contrato em questão. Pode haver, ainda, a existência de uma "cláusula flutuante", que passa ao demandante o poder de optar pela legislação a ser aplicada bem como a competência.

Importante frisar que, além do regime jurídico a ser adotado, esta cláusula também poderá indicar, a título de responsabilização pelo transporte de carga evidenciado pelo conhecimento de embarque (BL), a incidência das regras da Convenção de Bruxelas para a Unificação de Certas Regras em Matéria de Conhecimento de Embarque (International Convention for the Unification of Certain Rules of Law relating to Bill of Lading), que são conhecidas como Regras de Haia-Visby, ou optar pela 
aplicabilidade das Regras de Hamburgo, convenções estas que serão analisadas mais detalhadamente.

Por último, cabe transcrever a cláusula paramount utilizada nos contratos padrão de fretamento aprovada pela BIMCO - The Baltic \& International Maritime Council ${ }^{16}$, organização privada com sede na Dinamarca, cuja função primordial é a estruturação da normativa jurídica do transporte marítimo:

"The International Convention for the Unification of Certain Rules of Law relating to Bills of Lading signed at Brussels on 25 August 1924 ("the Hague Rules") as amended by the Protocol signed at Brussels on 23 February 1968 ("the Hague-Visby Rules") and as enacted in the country of shipment shall apply to this Contract. When the Hague-Visby Rules are not enacted in the country of shipment, the corresponding legislation of the country of destination shall apply, irrespective of whether such legislation may only regulate outbound shipments.

When there is no enactment of the Hague-Visby Rules in either the country of shipment or in the country of destination, the Hague-Visby Rules shall apply to this Contract save where the Hague Rules as enacted in the country of shipment or if no such enactment is in place, the Hague Rules as enacted in the country of destination apply compulsorily to this Contract.

The Protocol signed at Brussels on 21 December 1979 ("the SDR Protocol 1979") shall apply where the Hague-Visby Rules apply, whether mandatorily or by this Contract.

The Carrier shall in no case be responsible for loss of or damage to cargo arising prior to loading, after discharging, or while the cargo is in the charge of another carrier, or with respect to deck cargo and live animals."

Date: $01.10 .97^{, 17}$

"A Convenção de Bruxelas para a Unificação de Certas Regras em Matéria de Conhecimento de Embarque (Bill of Lading) assinada em Bruxelas em 25 de agosto de 1924 (Convenção de Haia) complementada pelo Protocolo assinado também em Bruxelas em 23 de fevereiro de 1968 (Regras de Haia-Visby) e uma vez prevista no país de embarque ela deverá ser aplicada ao Contrato.

Quando as Regras de Haia-Visby não são aplicáveis no país de embarque a legislação correspondente do país de destinação é ativada (deve ser aplicada), ainda que esta legislação somente trate de embarques para o exterior.

Quando não se aplicam as Regras de Haia-Visby em ambos os países de embarque ou destino, a Haia-Visby deve reger o contrato, salvo onde as regras de Haia são aplicáveis no país de embarque, ou se tal regra não for aplicável no

16 Organização internacional privada, formada na Dinamarca em 1905 por armadores e operadores do ramo do transporte marítimo internacional. www.bimco.org

${ }^{17}$ https://www.bimco.org/en/Members/Chartering/BIMCO\%20Clauses/Paramount Clause Gene ral.aspx 
país de embarque, mas for aplicável no país de destinação, a Convenção de Haia será aplicada compulsoriamente a este Contrato.

O Protocolo assinado em Bruxelas em 21 de dezembro de 1979 (Protocolo SDR de 1979), é aplicável onde as Regras de Haia-Visby são aplicáveis, tanto no caso de mandatórias como por Contrato. $O$ transportador não deverá em hipótese alguma ser responsável por perdas ou danos à carga que chega, antes do embarque, após o embarque, ou enquanto a carga estiver sob responsabilidade de outro transportador, ou se for o caso de carga no deck ou se tratar de animais vivos." (tradução livre).

Pela simples leitura desta cláusula padrão, resta claro que a incidência das Regras de Haia-Visby se dá tão-somente nos casos de transporte de mercadorias, não sendo aplicadas nas demais formas de afretamento.

As cláusulas de exceção geral, são aquelas que especificam as situações de excludentes de responsabilidade do armador. Chamadas cláusulas limitativas de responsabilidade, ou, ainda, Limitation Clause, são de suma importância para a hipótese de responsabilização civil por eventuais avarias durante o transporte marítimo, umas vez que esta modalidade de transporte possui riscos inerentes. As hipóteses abrangidas pela cláusula de exceção devem ser analisadas conjuntamente com a cláusula paramount.

Ademais, as cláusulas de negligência, são aquelas que pretendem impedir a responsabilização do armador. $\mathrm{O}$ ônus da prova da negligência do mesmo cabe ao afretador, sendo de sua responsabilidade fazer prova de que o armador não agiu com a devida diligência no transporte marítimo. O ônus será invertido nos casos em que houver o chamado "falta lucrativa", que resulta em benefício ao armador.

As cláusulas de despesas de carga e descarga são aquelas que estabelecem as condições básicas de frete. Dentro desta hipótese, verifica-se a existência de determinados termos básicos que indicam as condições acordadas, dentre eles: 
i.FIO - free in and out: significa dizer que o armador está isento das despesas com o embarque, estiva e desembarque das mercadorias, cabendo, tão-somente, a obrigação do transporte do porto de embarque ao porto de destino;

ii.FI - free in: o armador fica isento apenas das despesas de embarque e estiva;

iii.FO - free out: o armador não fica responsável pelos custos do desembarque das mercadorias.

A cláusula de indenização tem como objetivo a garantia de que uma indenização será paga caso não haja o cumprimento do contrato, indenização esta que não pode ultrapassar o montante do frete.

Importante destacar, por último, o chamado off-hire clause (ou breakdown clause). Off-hire diz respeito às hipóteses de suspensão do contrato de afretamento por indisponibilidade do navio, não havendo o pagamento do frete. O não pagamento do frete pode ser total (off-hire total) ou parcial (off-hire pro rata), dependendo se a indisponibilidade for total ou apenas se restringir à parte do navio. A off-hire clause, portanto, é aquela que prevê a suspensão do contrato de fretamento na ocorrência de qualquer causa que torne o navio indisponível. A situação de indisponibilidade da embarcação é provada mediante o chamado off-hire certificate, que será assinado pelo comandante e pelo afretador, devendo mencionar a hora em que a interrupção se deu, bem como a quantidade de água e óleo existentes.

Esta situação de indisponibilidade do navio está prevista pelo artigo 476 do Código Civil, referindo-se ao exceptio nom adimpleti contractus, ou exceção do contrato não cumprido: "Art. 476: Nos contratos bilaterais, nenhum dos contratantes, antes de cumprida a sua obrigação, pode exigir o implemento da do outro".

A parte lesada pelo estado de indisponibilidade do navio poderá, além de suspender o pagamento do frete, total ou parcialmente, rescindir o 
contrato com perdas e danos, caso haja lesão pelo inadimplemento com culpa, ou, ainda, exigir o cumprimento do contrato com indenização por perdas e danos.

Ainda no que se refere à carta-partida, importante mencionar, por último, o chamado booking note, documento emitido pelo fretador, que apesar de ser útil na fase pré-contratual da carta-partida, não se confunde com a mesma. Trata-se de um documento que evidencia a reserva de praça, ou seja, que demonstra haver a reserva de determinado espaço em um navio para transporte de certa mercadoria.

\subsection{Espécies de Afretamento}

As modalidades de afretamento de embarcações são divididas quanto à exploração comercial do navio e ao espaço fretado, havendo a combinação de ambas as subdivisões. Primeiramente, no que tange à exploração do navio, há três tipos de afretamento: afretamento a casco nu (bareboat charter party/ by demise charter party), por viagem (voyage charter), por tempo (time charter). Há, ainda, as modalidades referentes ao espaço fretado, que são: afretamento total e afretamento parcial.

Estas classificações são delimitadas pelo artigo $2^{\circ}$ da Lei 9.432 de 1997, que dispõe sobre a ordenação do transporte aquaviário, como restará, mais adiante, demonstrado.

Antes de adentrar nas especificações de cada forma de afretamento, é preciso delimitar os conceitos de gestão náutica e gestão comercial do navio, para um maior entendimento da questão. A gestão náutica diz respeito à armação do navio, ou seja, à organização no que tange à manutenção, tripulação, seguros, etc. A gestão comercial, por outro lado, está relacionada às questões de carga e descarga de mercadorias, bem como às escalas e portos de embarque e destino. 
A especificação destes dois tipos de gestão é de suma importância para a análise de responsabilização pelos fatos ocorridos na execução do contrato, uma vez que delimita as obrigações de cada uma das partes contratantes. Note que a distribuição das obrigações varia com o tipo de afretamento contratado, como será demonstrado.

Para maiores esclarecimentos, destaca-se trecho da obra da maritimista Carla Adriana Gibertoni:

"Como já foi explicado, a gestão náutica diz respeito à navegação em geral, abrangendo a manutenção, conservação, aprovisionamento, administração pessoal, etc. A gestão comercial engloba os assuntos respeitantes à carga e ao frete, como angariar e fechar contratos, recebimento e entrega, conclusão de contratos de afretamento, relacionamento com corretores, etc.", 18

\subsubsection{Afretamento por Tempo ou a Prazo}

Também chamado de Time Charter Party, este tipo de contrato trata da hipótese em que o fretador assume a responsabilidade de dispor o navio completamente armado e tripulado à pessoa do fretador, por tempo determinado, havendo a contraprestação do frete. Neste caso, não há a transferência da posse da embarcação, que permanece sendo do fretador/armador.

O inciso II do artigo $2^{\circ}$ da Lei 9.432/97 define esta espécie de contrato, não havendo:

“Art. $2^{\circ}$ Para efeitos desta Lei, são estabelecidas as seguintes definições:

II - afretamento por tempo: contrato em virtude do qual o afretador recebe a embarcação armada e tripulada, ou parte dela, para operá-la por tempo determinado;"

Não há, contudo, legislação que regule o tema de forma mais aprofundada, configurando-se, portanto, um contrato atípico. Por conta da existência dessa vasta lacuna, aplica-se por analogia o Código Brasileiro de Aeronáutica, que prevê o afretamento por tempo de aeronaves, e as regras

\footnotetext{
${ }^{18}$ GIBERTONI, Carla Adriana Comitre. Teoria e Prática do Direito Marítimo. Rio de Janeiro: Renovar, 2005, p. 183.
} 
de locação de serviços previstas pelo Código Civil nos artigos 593 e seguintes.

Dentre as responsabilidades do armador-fretador encontra-se o dever de colocar o navio à disposição do fretador e de garantir o seu estado de navegabilidade. Além disso, o armador-fretador deve realizar as viagens contratadas com a maior eficiência possível (utmost despatch).

Quanto às obrigações do afretador, estas consistem no dever de pagar o frete, de receber e utilizar o navio da maneira convencionada, de arcar com os gastos referentes à água e combustível, despesas portuárias e de praticagem, bem como qualquer outra taxa imposta à embarcação. Há, ainda, o dever de restituir o navio, momento no qual deverá ser realizada uma vistoria conjunta de forma a averiguar eventuais danos causados ao navio. O tempo utilizado além do acordado é chamado de overlap e deverá ser pago (frete).

Carla Adriana Gibertoni faz uma analogia interessante quanto à responsabilidade de cada parte nos contratos de afretamento por tempo:

"A natureza jurídica do time charter equipara-se, na lição de Sampaio Lacerda, aos contratos de cofres-fortes ou cofres de segurança que certos bancos alugam a particulares para a guarda de jóias, documentos, objetos de valores, etc. Exatamente como acontece na time charter, a administração das instalações continua a cargo do estabelecimento bancário (locador). O único interesse do armador-locatário é a realização de viagens, na vigência do contrato dentro das condições ajustadas". ${ }^{19}$

Importante observar que no trecho acima transcrito a autora se refere ao time charter como sendo um contrato de locação ao utilizar a expressão "armador-locatário", o que vai de acordo com a corrente doutrinária a qual a mesma está afiliada. Entretanto, como já demonstrado no presente trabalho, defende-se aqui o entendimento de que os contratos de afretamento marítimo possuem diversas modalidades distintas, dependendo

\footnotetext{
${ }^{19}$ GIBERTONI, Carla Adriana Comitre. Teoria e Prática do Direito Marítimo. Rio de Janeiro: Renovar, 2005, p. 181.
} 
da utilização a ser dada ao navio, não estando relacionados com o instituto da locação.

\subsubsection{Afretamento a Casco Nu}

Esta modalidade de fretamento é caracterizada pelo fato da posse do navio passar para a pessoa do afretador, uma vez que este assume o controle total sobre a operação do navio por um tempo determinado. $\mathrm{O}$ armador fica conhecido como proprietário pro hac vice ("nesta situação particular"). Neste caso, a armação do navio é feita pelo afretador, que detém controle total sobre o mesmo. Portanto, tanto a gestão náutica quanto a gestão comercial são de responsabilidade da parte que afretou o navio.

Cabe ao fretador, proprietário do navio, a responsabilidade tãosomente sobre custos de capital do navio (como, por exemplo, impostos e empréstimos), além do dever de entregar a embarcação em bom estado de navegabilidade, sendo este o "traço predominante" do afretamento a casco nu, como descrito por Carla Adriana Gibertoni. ${ }^{20}$

$\mathrm{O}$ artigo $2^{\circ}$, inciso I da Lei $9.432 / 97$ conceitua esta espécie de afretamento:

"Art. $2^{\circ}$ Para efeitos desta Lei, são estabelecidas as seguintes definições:

I - afretamento a casco nu: contrato em virtude do qual o afretador tem a posse, o uso e o controle da embarcação, por tempo determinado, incluindo o direito de designar o comandante e a tripulação;"

Também são chamados de Bare Boat Charter Party ou Demise Charter Party. Importante mencionar uma peculiaridade existente no direito inglês quanto a estas terminologias - a diferença entre essas duas nomenclaturas reside no fato que no Demise Charter Party o fretador pode nomear o chefe de máquinas e o comandante do navio através da inserção

\footnotetext{
${ }^{20}$ GIBERTONI, Carla Adriana Comitre. Teoria e Prática do Direito Marítimo. Rio de Janeiro: Renovar, 2005, p. 179.
} 
de uma cláusula denominada management clause, o que não se admite nos casos de Bare Boat Charter Party.

Eliane Martins sustenta que essa espécie contratual possui uma natureza jurídica híbrida, por possuir características tanto dos afretamentos por tempo quanto por viagem, ou seja, é um tipo de afretamento que dura um tempo determinado e possui rotas predefinidas, roteiro este que fica registrado na carta-partida. ${ }^{21}$

Cumpre ao fretador a obrigação de prestar o navio em bom estado de navegabilidade no tempo e local convencionados entre as partes, bem como de pagar os custos incidentes sobre o navio. No que tange às obrigações da parte afretadora, deve-se frisar novamente que este detém a posse temporária do navio, sendo, portanto, responsável tanto pela gestão náutica quanto pela gestão comercial do mesmo. Logo, o afretador deverá arcar com todos os demais custos, como, por exemplo, as despesas com manutenção do navio, sem prejuízo do devido pagamento do hire, frete que será calculado de acordo com o tempo acordado e levando-se em conta a tonelagem da carga e o tempo em que o navio ficou parado para reparos de vícios não próprios da embarcação, o que pode ser discutido nas hipóteses de caso fortuito ou força maior.

\subsubsection{Afretamento por Viagem}

Os contratos de afretamento por viagem são aqueles em que o fretador coloca a disposição do afretador um navio para a realização de viagens específicas, cabendo ao fretador tanto a gestão náutica quanto a gestão comercial da embarcação. A duração do contrato está associada ao roteiro que o navio irá seguir do porto de embarque ao porto final, enquanto $\mathrm{o}$ valor do frete é definido de acordo com a tonelagem da carga. $\mathrm{O}$ artigo $2^{\circ}$, inciso III da Lei 9.432/97 estabelece o seguinte:

\footnotetext{
${ }^{21}$ MARTINS, Eliane M. Octaviano. Curso de Direito Marítimo Vol. II. Barueri, São Paulo: Manole, 2008, p.209.
} 
“Art. $2^{\circ}$ Para efeitos desta Lei, são estabelecidas as seguintes definições:

III - afretamento por viagem: contrato em virtude do qual o fretador se obriga a colocar o todo ou parte de uma embarcação, com tripulação, à disposição do afretador para efetuar transporte em uma ou mais viagens;"

Os afretamentos por viagem se dividem em duas subespécies: o fretamento contratado para apenas uma viagem (Single Voyage Charter Party) e o contratado para a execução de mais de uma viagem (Consecutive Voyage Charter Party).

Salienta-se divergência doutrinária existente acerca da natureza jurídica desta espécie contratual. Para parte da doutrina trata-se de contrato de afretamento propriamente dito. Por outro lado, alguns doutrinadores sustentam que, na realidade, o contrato de afretamento por viagem nada mais é que um contrato de transporte. Defende-se, como previamente sustentado, que os contratos de fretamento têm como objetivo a exploração de um navio específico, o que não significa que este será necessariamente utilizado para o transporte de mercadorias e pessoas. $\mathrm{O}$ contrato de transporte propriamente dito diz respeito às mercadorias que serão transportadas, e não ao navio.

Uma das cláusulas mais importantes nos contratos de afretamento por viagem é a cláusula laydays (estadia), que estipula a data provável para início do carregamento e a data limite para a devolução do navio por parte do afretador ao fretador. A sobreestadia, usualmente denominada demurrage, se dá quando o navio ultrapassa o tempo máximo estipulado, havendo, nestes casos, o devido pagamento de uma multa. Em contrapartida, existe um prêmio a ser pago pelo fretador caso o navio seja entregue antes do prazo estipulado, situação esta denominada subestadia (despatch Money).

Por oportuno, analisa-se a responsabilidade de cada uma das partes contratantes na modalidade de afretamento em tela. Cabe ao fretador dispor o navio em perfeito estado de navegabilidade no local e data acordado, não havendo a partilha da gestão, ou seja, o fretador é responsável tanto pela 
gestão náutica quanto pela comercial. Ao afretador incide a responsabilidade pelo pagamento do frete e por colocar a mercadoria à disposição do fretador para embarque.

Muito embora seja pouco utilizada na prática, esta modalidade de afretamento possui certas vantagens para o embarcador, no ponto de vista comercial, uma vez que este não fica sujeito às instabilidades do mercado.

\subsubsection{Do Contrato de Afretamento Total e Parcial}

Resta demonstrar as modalidades quanto ao espaço afretado, quanto à utilização espacial do navio. No afretamento total, como o próprio nome demonstra, o navio é disponibilizado ao afretador em sua totalidade, enquanto no afretamento parcial há a disposição de parte do navio, havendo a contratação com diversos embarcadores.

Carla Adriana Gibertoni explica que:

"O fretamento parcial é mais comum devido ao grande porte dos navios. É da mesma natureza do fretamento total, diferenciando-se apenas em razão do local ocupado pelas mercadorias a bordo do navio. Trata-se de uma questão material e não jurídica. ${ }^{, 22}$

$\mathrm{Na}$ combinação de ambas as modalidade deve-se ressaltar que o contrato a casco nu só poderá se dar quando houver o afretamento total do navio, o que não ocorre nos contratos por viagem ou por tempo, em que poderá haver o afretamento parcial.

Finalmente, cabe aqui transcrever o artigo 566 do Código Comercial:

Art. 566. O contrato de fretamento de qualquer embarcação, quer seja na sua totalidade ou em parte, para uma ou mais viagens, quer seja à carga ou colheita ou prancha, o que tem lugar quando o capitão recebe carga de quantos se apresentam, deve provar-se por escrito. No primeiro caso o instrumento que se chama carta-partida ou carta de fretamento, deve ser assinado pelo fretador e

\footnotetext{
${ }^{22}$ GIBERTONI, Carla Adriana Comitre. Teoria e Prática do Direito Marítimo. Rio de Janeiro: Renovar, 2005, p. 182.
} 
afretador, e por quaisquer outras pessoas que intervenham no contrato, do qual se dará a cada uma das partes um exemplar; e no segundo, o instrumento chamase conhecimento, e basta ser assinado pelo capitão e carregador. Entende-se por fretador o que dá, e por afretador o que toma a embarcação a frete".

Não obstante a determinação de que em se tratando de afretamento parcial o instrumento a ser utilizado será o conhecimento marítimo (BL), é comum que esta espécie seja concretizada mediante carta-partida. A doutrina entende que esta disposição acaba por ser revogada diante da prática reiterada de celebração de carta-partida em afretamento parcial. Logo, prevalece o entendimento de que o contrato de afretamento parcial pode se dar tanto pelo conhecimento de embarque marítimo quanto pela carta-partida.

\subsection{Responsabilidade das Partes Contratantes}

Dentre as responsabilidades da pessoa do fretador, destaca-se, primeiramente, a obrigação de disponibilizar a embarcação em data e local acordado e em perfeito estado de navegabilidade, ou seja, com equipamentos, documentos e estrutura apta à expedição marítima, além de capacidade para transportar a carga (freightage), conforme convencionado entre as partes. Como bem expõe Eliane Martins: "Nota-se, portanto, que a expressão navegabilidade, na acepção ampla abrange navegabilidade técnica, operacional e funcional". ${ }^{23}$

Mais adiante, importante diferenciar dois conceitos criados pela doutrina: navegabilidade absolta e relativa. A navegabilidade absoluta (seaworthiness) diz respeito à plena capacidade de navegar sobre águas, de transladar, o que está necessariamente relacionado ao estado de flutuabilidade. A navegabilidade relativa (cargoworthiness), por sua vez, relaciona-se às questões operacionais do navio, devendo estar de acordo com os objetivos do tipo de afretamento pactudado pelas partes

\footnotetext{
${ }^{23}$ MARTINS, Eliane M. Octaviano. Curso de Direito Marítimo Vol. II. Barueri, São Paulo: Manole, 2008, p.179.
} 
contratantes. Os estados de inavegabilidade absoluto ou relativa, por óbvio, representam o contrário do aqui exposto.

Ademais, configura-se de responsabilidade do afretador o pagamento do frete ao fretador ou ao seu agente ou broker (o que pode estipulado de forma diversa, por exemplo, determinando que o pagamento deverá ser feito ao comandante do navio), além da recepção e devolução do navio nas condições convencionadas.

No âmbito do pagamento do frete, cumpre destacar o fato de que o Conhecimento de Embarque (Bill of Lading) pode estipular que a obrigação de pagar caberá à terceiro (por exemplo, consignatário ou endossatário do BL), o que não afasta a responsabilidade do afretador por eventual inadimplemento, cabendo direito de regresso. Isso se dá diante do fato de que o contrato foi firmado entre as pessoas do fretador e afretador, sendo terceiros estranhos à relação, não havendo qualquer vínculo. Neste sentido, leciona com maestria Eliane Martins:

"É evidente que a relação direta existe da relação negocial originária entre fretador e afretador. Via de conseqüência, qualquer outro terceiro interveniente na relação posterior ao contrato de fretamento principal e decorrente da utilização, pelo afretador, do navio em subfretamente ou em contratos de transporte, são sujeitos estranhos ao fretador. Destarte, os subfretadores, embarcadores, consignatários e endossatários do BL são terceiros e inexiste qualquer vínculo de direito pessoal com o fretador". ${ }^{24}$

Trata-se a hipótese descrita de subfretamento, no qual o sub-frete será pago pelo terceiro, sub-afretador, ao afretador, que, no caso, assume o papel de sub-fretador.

Ainda quanto ao pagamento do frete, analisa-se o tempo do pagamento. Nesta seara, verifica-se três tempos para pagamento do frete. Primeiramente, pode haver o chamado Freight payable at destination collect, que indica que o pagamento será efetuado na entrega da mercadoria. Quando fica convencionado que o frete será pago em local distinto dos

\footnotetext{
${ }^{24}$ MARTINS, Eliane M. Octaviano. Curso de Direito Marítimo Vol. II. Barueri, São Paulo: Manole, 2008, p.183.
} 
portos de embarque e desembarque tem-se o chamado Freight Collect. Por último, verifica-se o Freight Prepaid, que, como o próprio nome indica, é o frete pago antecipadamente.

Finalmente, de suma importância analisar a responsabilidade do fretador e do armador perante terceiros, o que está necessariamente relacionado ao dano causado. Se o dano foi causado em decorrência da exploração comercial do navio, a responsabilidade será do fretador, à quem cabe a gestão comercial do navio. Por outro lado, se a hipótese fática possui nexo causal com questões atinentes às condições do navio, a responsabilidade será do armador-fretador, uma vez que este responde pela gestão náutica.

\subsection{Resolução dos Contratos de Afretamento}

A resolução dos contratos de afretamento segue basicamente os mesmos contornos da resolução dos contratos usuais. O artigo 571 do Código Comercial prevê as hipóteses que resultaram na resolução dos contratos de afretamento, in verbis:

"Art. 571. Dissolve-se o contrato de fretamento, sem que haja lugar a exigência alguma de parte a parte:

1. se a saída da embarcação for impelida, antes da partida, por força maior, sem limitação de tempo;

2. sobrevindo, antes de precipitada a viagem, declaração de guerra, ou interdito de comércio com o país para onde a embarcação é destinada, em conseqüência do qual o navio e a carga conjuntamente não sejam considerados como propriedade neutra;

3. proibição de exportação de todas ou da maior parte das fazendas compreendidas na carta de fretamento do lugar donde a embarcação deve partir, ou de importação no de seu destino;

4. declaração de bloqueio do porto da carga ou do seu destino, antes da partida do navio.

Em todos os referidos casos as despesas da carga serão por conta do afretador ou carregadores".

No geral, o inadimplemento por parte do fretador é caracterizado pela indisponibilidade do navio, podendo o afretador optar pela rescisão do 
contrato. Por parte do afretador, a inadimplência é configurada mediante a ausência de pagamento do frete, podendo ensejar à resolução ou suspensão do contrato.

Por último, vale destacar a hipótese em que o capitão oculta a bandeira do navio do armador, podendo este último requerer a rescisão do contrato, nos termos do artigo 574 do Código Comercial:

“Art. 574. Poderá igualmente rescindir-se o contrato de fretamento a requerimento do afretador, se o capitão lhe tiver ocultado a verdadeira bandeira da embarcação; ficando este pessoalmente responsável ao mesmo afretador por todas as despesas da carga e descarga, e por perdas e danos se o valor do navio não chegar para satisfazer o prejuízo". 


\section{CAPÍTULO 3 - DOS CONTRATOS INTERNACIONAIS DE TRANSPORTE DE MERCADORIAS POR MAR}

\subsection{Noções Gerais}

Primeiramente, cumpre diferenciar dois conceitos básicos para o ramo do Direito Marítimo: tráfico marítimo e tráfego marítimo. O tráfico marítimo refere-se ao comércio marítimo, à atividade empresarial e exploração do navio como meio de transporte. $\mathrm{O}$ tráfego, por seu turno, diz respeito ao deslocamento, ao trânsito da embarcação, ou, ainda, à "arte de navegar". Após esta breve análise, pode-se dizer que o tráfico marítimo depende necessariamente do tráfego marítimo.

O contrato de transporte marítimo é o instrumento através do qual o transportador se obriga, mediante o pagamento do frete, a transportar por mar, do porto de embarque ao porto de destino, a mercadoria que lhe foi conferida pelo embarcador, com o dever de entregá-la ao destinatário/consignatário.

$\mathrm{O}$ conceito de frete abrange tanto o frete relacionado ao fretamento quanto o frete referente ao transporte propriamente dito, o qual é conhecido como Freight Line Charges, ou, simplesmente, Freight.

Figuram como partes desta relação contratual o transportador marítimo ou condutor, o embarcador ou expedidor e o consignatário. $\mathrm{O}$ transportador é a parte responsável pela realização do transporte da mercadoria, não sendo necessariamente o armador ou proprietário da embarcação. O embarcador, por sua vez, é a parte que contrata o transporte e fornece as mercadorias ao transportador. Finalmente, o consignatário é aquele que recebe as mercadorias transportadas no porto de destino.

Não obstante o contrato de transporte seja uma forma de utilização do navio, o mesmo não se confunde com o contrato de afretamento, como sustentado anteriormente. 
No plano nacional os contratos de transporte são regidos pelo Código Civil e pelo Código Comercial, enquanto no cenário internacional há a incidência das Regras de Haia, Regras de Haia-Visby e as Regras de Hamburgo, que serão analisadas neste capítulo.

O transporte marítimo possui duas categorias de navegação: o tráfico marítimo regular, também conhecido como navegação liner, que diz respeito aos navios que seguem rotas previamente estabelecidas, e o tráfico marítimo não regular, que, por sua vez, trata das navegações livres, que variam de acordo com a demanda dos embarcadores, não havendo uma regularidade nas rotas.

Importante frisar por último que a utilização dos Incoterms na formação dos contratos de compra e venda mercantil se tornou cada vez mais comum, através de siglas que indicam padrões adotados pelo instrumento contratual. Cabe ressalvar, contudo, que os contratos que prevêem cláusulas Incoterms estão relacionados à compra e venda da mercadoria propriamente dita, não se confundindo com o contrato de transporte. Destacam-se os dois Incoterms mais utilizados: FOB (Free on Board), que estabelece que o vendedor deverá entregar a mercadoria a bordo da embarcação, cabendo ao comprador os custos com frete e seguro do transporte; CIF (Cost Insurance \& Freight), que indica que o vendedor ficará responsável pelas despesas decorrentes do transporte da mercadoria comprada e do seguro do mesmo.

\subsection{Bill of Lading - Conhecimento de Embarque}

O contrato de transporte é evidenciado pelo chamado Conhecimento de Transporte Marítimo ou Conhecimento de Embarque (Bill of Lading $B L$ ), tido como um dos documentos mais importantes no comércio marítimo. 
Carla Adriana Gibertoni descreve com precisão o conhecimento de embarque: "Assim, o conhecimento faz prova do recebimento a bordo do navio das mercadorias nele descritas e a obrigação do transportador em entregá-la no lugar de destino à pessoa a quem vão consignadas. ${ }^{25}$

Diferentemente do que ocorre nos contratos de afretamento por viagem, no qual há o afretamento de toda a embarcação para o transporte de mercadorias, no transporte por conhecimento contrata-se apenas o transporte da mercadoria de um porto a outro, independentemente do navio a ser utilizado. É por essa razão que não se pode falar que o contrato de afretamento por viagem se confunde com o contrato de transporte, tendo em vista que o objeto essencial dos contratos não é o mesmo.

No geral, nas hipóteses em que há a contratação para o transporte de pequenos lotes de carga, os quais não ocupam a totalidade do navio, opta-se pela expedição do conhecimento de embarque. Por outro lado, quando a mercadoria ocupa a embarcação inteira, há o afretamento do navio como um todo, sendo a carta-partida o instrumento utilizado.

Nos contratos do tipo conhecimento de embarque a carga poderá ser transportada em contêineres, cujo frete será avaliado de acordo com o peso e o volume da carga ou com base no valor declarado da mercadoria, ou poderá ser transportada solta no porão do navio.

O conhecimento de embarque é um documento emitido pelo transportador e assinado pelo comandante no navio, que faz prova do recebimento a bordo da mercadoria, servindo ainda como evidência do próprio contrato de transporte. Carla Adriana Gibertoni explica que:

“(...) é o conhecimento, ao mesmo tempo, um recibo e um contrato de transporte, cujas cláusulas estão incorporadas ao mesmo, uma vez que trazem no verso as cláusulas que regem um contrato de transporte, inclui o contrato de transporte". ${ }^{26}$

\footnotetext{
${ }^{25}$ GIBERTONI, Carla Adriana Comitre. Teoria e Prática do Direito Marítimo. Rio de Janeiro: Renovar, 2005, p. 199.

${ }^{26}$ Ibid. p. 201.
} 
O transportador deve emitir três vias do conhecimento de embarque, sendo que a primeira é entregue ao embarcador, a segunda permanece com o transportador e a terceira é entregue ao consignatário da carga. Esta última via deverá ser apresentada no momento em que a mercadoria foi descarregada no porto final. O artigo 744 do Código Civil prevê está função do transportador: "Ao receber a coisa, o transportador emitirá conhecimento com a menção dos dados que a identifiquem, obedecido o disposto em lei especial”.

Além da função de evidência do contrato de transporte, o Conhecimento de Embarque tem a função de recibo, por servir como prova documental do recebimento da mercadoria para transporte, e de título de crédito, tendo em vista que a posse e a apresentação do mesmo pelo consignatário o legitima como proprietário da mercadoria junto ao capitão do navio - podendo ser um título nominativo, suscetível de endosso, ou ao portador. Cabe destacar que o conhecimento nominativo (Straight Bill of Lading) pode ser à ordem (Order Bill of Lading), o qual pode ser endossado, ou não à ordem, que não poderá ser objeto de endosso.

Desta forma, verifica-se que o Conhecimento de Embarque possui funções múltiplas, sendo de suma importância para o transporte de mercadorias por mar, exercendo, ainda, papel fundamental da delimitação da responsabilidade por eventuais avarias.

\subsection{Convenções Internacionais}

A Convenção Internacional para a Unificação de Certas Regras em Matéria de Conhecimento de Embarque (International Convention for the Unification of Certain Rules of Law relating to Bill of Lading), conhecida como Regras de $\mathrm{Haia}^{27}$, foi uma das primeiras tentativas de sistematização

\footnotetext{
${ }^{27}$ A Convenção Internacional para a Unificação de Certas Regras em Matéria de Conhecimento de Embarque de 1924, apesar de ter sido assinada em Bruxelas, é usualmente denominada 'Regras de Haia', uma vez que foi elaborada com base nas Regras de Haia de 1921, que por sua
} 
das normas de Direito Marítimo. Estas regras adotavam a linha de responsabilidade moderada do transportador marítimo, havendo a previsão algumas hipóteses de exoneração da responsabilidade do transportador em casos de perdas ou avarias da carga.

As isenções previstas excluem a responsabilidade do transportador nas seguintes hipóteses: incêndio, perigos do mar, falta náutica, atos de guerra, greves, culpa do embarcador, desvio de rota em função de salvamento, embalagem inadequada, vício inerente à mercadoria, e atos que não decorram de culpa do transportador e seus agentes.

Ao mesmo tempo impõe obrigações mínimas aos transportadores, tais como dever de diligência mínima (due diligence) e boas condições de navegabilidade.

Posteriormente, estas regras sofreram algumas modificações com o Protocolo de $\mathrm{Visby}^{28}$, passando a ser conhecidas como Regras de HaiaVisby, que seguem os mesmos moldes das Regras de Haia, tendo majorado o limite de responsabilização do transportador. Trata-se de uma linha de responsabilidade moderada do transportador marítimo, sendo importante frisar que as Regras de Haia-Visby somente são aplicadas à navegação internacional, não incidindo em hipóteses de cabotagem ou navegação interna.

Numa tentativa de equilibrar os interesses de ambas as partes contratantes, foi criada a Convenção das Nações Unidas sobre o Transporte Marítimo (United Nations Convention on the Carriage of Goods by Sea),

vez, foram elaboradas pelo Comitê Marítimo Internacional. Dentre os países que ratificaram as Regras de Haia de 1924 estão Alemanha, Argentina, Austrália, Bahamas, Barbados, Bélgica e Bolívia, China, Cingapura, Dinamarca, Espanha, Estados Unidos, França, Itália, Japão, Paraguai, Peru, Portugal e Reino Unido.

28 Convenção de Bruxelas de 1968. Considera-se que os países que recepcionaram essa convenção passaram a adotar também as Regras de Haia de 1924. Dentre os signatários estão: Alemanha, Argentina, Bélgica, Bermudas, Camarões, China, Croácia, Dinamarca, Egito, Equador, Espanha, Estados Unidos, Filipinas, Finlândia, França, Geórgia, Gibraltar, Grã-Betanha, Grécia, Hong-Kong, Ilhas Cayman, Ilhas Falkland, Ilhas Virgens, Irlanda do Norte, Irlanda do Sul, Itália, Letônia, Líbano, Libéria, Mauritânia, Montserrat, Noruega, Países Baixos, Paraguai, Polônia, Noruega, Singapura, Síria, Suécia, Suiça, Tonga, Uruguai, Vaticano e Zaire. 
também chamada de Regras de Hamburgo ${ }^{29}$. Essa convenção aplica o princípio da presunção de culpa do transportador, majorando os limites de responsabilização e reduzindo as hipóteses de isenção de culpa.

Paulo Campos Fernandes e Walter de Sá Leitão explicam que:

"As Regras de Hamburgo surgiram como uma resposta dos que atuam a favor dos interesses da carga contra as disposições das regras de Haia que tendem a beneficiar o transportador em detrimento da carga. Em uma nova Convenção tentou-se fazer com que a alocação de riscos, direitos e obrigações com relação a responsabilidade passassem a favorecer um pouco mais o embarcador do que o transportador. Assim, em março de 1978, em Hamburgo, por ocasião de uma Conferência Internacional da ONU, foi criada a Convenção Internacional para o Transporte de Mercadorias pelo Mar da ONU. Estas regras não tiveram grande aceitação internacional. Apenas 29 países as adotaram, sendo que muitos deles sequer costeiros são. Dentre os países que aderiram as Regras de Hamburgo estão Chile, Egito e Hungria. A Alemanha apenas sediou a conferência, porém não aderiu aos seus termos, tendo esta nação se alinhado com as Regras de Haia-Visby. "30

A diferença primordial entre as Regras de Haia-Visby e as de

Hamburgo está no limite de responsabilização do transportador marítimo. Enquanto nas Regras de Haia-Visby a responsabilidade do transportador se dá apenas enquanto a mercadoria se encontra na embarcação, nas Regras de Hamburgo a responsabilização é estendida pelo tempo em que a carga estiver sob os cuidados do transportador.

Por esta característica 'pró-carga', verifica-se uma aplicação limitada das Regras de Hamburgo, uma vez que estas vão de encontro com os interesses dos transportadores.

Visando uma maior unidade das regras referentes ao assunto no cenário internacional, foram criadas as Regras de $\operatorname{Roterdă}^{31}$, que

\footnotetext{
${ }^{29}$ As Regras de Hamburgo foram assinadas em 1978, mas apenas entraram em vigor em 1992, com a ratificação, aceitação ou adesão de 20 países, dente eles: Áustria, Barbados, Botswana, Brasil, Burkina Faso, Camarões, Chile, República Tcheca, Egito, Gâmbia, Geórgia, Romênia, São Vicente e Granadinas, Senegal, Síria, Serra Leoa, Tanzânia, Tunísia, Uganda e Zâmbia.

${ }^{30}$ FERNANDES, Paulo Campos; SÁ LEITÃO, Walter de. Responsabilidades no Transporte Maríimo. São Paulo. Aduaneiras, 2010. Pg. 55-56.

31 As Regras de Roterdã (Convenção das Nações Unidas sobre Contratos de Transporte Internacional de Mercadorias Total ou Parcialmente por Via Marítima) foram criadas em 2008 pela Comissão das Nações Unidas sobre Direito Comercial Internacional (UNCITRAL). Estas regras foram assinadas pelos seguintes países: Congo, Dinamarca, Espanha, Estados Unidos, França,
} 
estabelecem os direitos e obrigações no transporte de mercadorias por mar, objetivando atualizar os conceitos de Haia-Visby e das Regras de Hamburgo, de forma a aproximar estas convenções da atual realidade do comércio marítimo.

O Brasil, apesar de não ter ratificado, é signatário das Regras de Hamburgo, que, como acima exposto, têm aplicação limitada, sendo consideradas de pouca importância. Isto se dá pelo fato do Brasil ser um país com tendência a proteger a pessoa do importador e a carga, motivo pelo o qual não ratificou Haia ou Haia-Visby. Ao contrário do forte interesse marítimo no cenário internacional, o Brasil adota uma postura de proteção aos carregadores e recebedores das mercadorias. De qualquer forma, para que haja a produção de efeitos jurídicos destas convenções, não basta ser meramente signatário, devendo haver a ratificação.

Por conseguinte, o país resta defasado no aspecto jurídico da temática, não estando sujeito às normas marítimas mais influentes no cenário global, indo no sentido oposto da tendência internacional de harmonização das normas. Internamente prevalecem as normas internas referentes aos contratos de transporte em geral, que são aplicadas nos negócios marítimos nacionais, cada vez mais freqüentes.

Deste modo, não obstante o grande esforço despendido no sentido de maior uniformização da regras de direito marítimo, ainda há grande divergência entre os países.

\subsection{Responsabilidade das Partes Contratantes}

É dever do transportador marítimo conduzir com segurança a carga que lhe foi confiada até o porto de destino, em acordo com o disposto pelo artigo 749 do Código Civil: "O transportador conduzirá a coisa ao seu

Gabão, Gana, Grécia, Guiné, Holanda, Madagascar, Nigéria, Noruega, Polônia, Senegal, Suiça e Togo. Ainda não entraram em vigor, pois deve haver pelo menos 20 países. 
destino, tomando todas as cautelas necessárias para mantê-la em bom estado e entregá-la no prazo ajustado ou previsto".

$\mathrm{O}$ artigo 750 do mesmo diploma legal prevê, ainda, que o transportador é responsável pela incolumidade da carga a partir do momento em que a recebe, responsabilidade esta que cessa com a entrega ao depositário, estando limitada ao valor descrito no conhecimento de embarque. Cabe destacar que o comandante do navio figura como depositário da mercadoria recebida a bordo, em consonância com o disposto pelo artigo 519 do Código Comercial.

O ilustre jurista Orlando Gomes prevê o tempo desta responsabilidade, como segue no trecho transcrito:

"No transporte de coisas a carga da mercadoria considera-se ato de execução do contrato, presumindo-se que seja o elemento decisivo do expedido. As obrigações do transportador não surgem antes do recebimento das mercadorias, mas isso não impede a formação anterior do contrato, até porque ele contrai a obrigação de recebê-las

(...)

Desde esse momento, torna-se o transportador depositário das mercadorias recebidas emitindo conhecimento com a menção de sua natureza, qualidade, quantidade e peso. Nesse documento também registra o nome endereço e outros dados de identificação do destinatário", 32

É assegurado, ainda, o direito do transportador recusar a carga, caso verifique que a mesma se encontra em embalagem inadequada ou avariada, em consonância com o artigo 476: "Poderá o transportador recusar a coisa, cuja embalagem seja inadequada, bem como a que possa pôr em risco a saúde das pessoas, ou danificar o veículo e outros bens".

Ademais, o Decreto-Lei 116/67 dispõe sobre as operações inerentes ao transporte marítimo de mercadorias nos portos brasileiros e delimita a questão da responsabilidade quanto às faltas e avarias.

O transportador deverá informar qualquer avaria ou má acondicionamento da carga no momento do embarque, de forma a registrar o fato. Além disso, deverá fiscalizar as operações de embarque e

\footnotetext{
${ }^{32}$ GOMES, Orlando. Contratos. 26a ed. Rio de Janeiro, Forense, 2008. Pg. 376-377.
} 
desembarque, para garantir a integridade da mercadoria, sendo importante frisar que o ônus da prova é do transportador, devendo demonstrar as causas excludentes de responsabilidade.

No que tange às obrigações do embarcador, destaca-se, primordialmente, o pagamento do frete e, caso esse pagamento não seja efetuado, poderá o transportador ajuizar uma ação de cobrança, havendo, no geral, a responsabilidade solidária entre o embarcador e o consignatário.

Por último, cumpre delimitar a responsabilidade do destinatário/consignatário, que deve receber a mercadoria descarregada, de acordo com as condições estabelecidas no Conhecimento de Embarque. Por exemplo, o conhecimento pode prever a cláusula Freight Payable at Destination Collect (Frete Pagável no Destino) ou Freight to Be Paid Before Breaking Bulk (antes da descarga), devendo o destinatário efetuar o pagamento.

O consignatário deverá, ainda, averiguar a mercadoria desembarcada, devendo apresentar protesto no ato de descarga caso seja verificada qualquer avaria ou perda na carga.

Ainda no tocante ao tema da responsabilidade nos contratos de transporte, de suma importância destacar a cláusula limitativa de responsabilidade do transportador, bastante utilizada atualmente. Esta cláusula prevê a limitação da responsabilidade do transportador por eventuais avarias, reduzindo o valor a ser indenizado.

Com a declaração do valor da carga, o frete é calculado sobre o real valor do bem transportado (frete ad valorem). Por outro lado, se o valor não é declarado, este cálculo será feito sobre a dimensão da carga (frete ad rem), havendo a redução do valor devido. Desta forma, ao não declarar o valor da carga, o embarcador acaba por reduzir o frete, incidindo, em contrapartida, a limitação da responsabilidade do embarcador por eventuais 
avarias. Caso o embarcador queira ser totalmente indenizado, ele deverá indicar o valor da mercadoria no BL, encarecendo o valor do frete.

A despeito de parte da doutrina se posicionar contra esta cláusula, por entender que a mesma pode gerar situações desproporcionais, em que o valor da indenização fica muito abaixo do real dano, a jurisprudência tem reconhecido a validade da mesma, como segue no aresto abaixo colacionado:

"VALIDADE DA CLAUSULA DE LIMITAÇÃO DA RESPONSABILIDADE Se o embarcador paga apenas o frete normal da mercadoria, correspondente ao valor declarado no conhecimento, sem indicar um valor maior como sendo o real valor da mercadoria transportada."

(STJ, AGA 27580, Min. Athos Carneiro, DJ 22.03.93, p. 4548)

Além disso, em detalhado julgamento proferido pelo Egrégio Tribunal de Justiça do Estado de São Paulo, restou muito bem ilustrada essa questão, tendo se posicionado no sentido da validade das cláusulas limitativas de indenização, destacando, ainda, outros precedentes com o mesmo entendimento:

"CLÁUSULA LIMITATIVA DE INDENIZAR - CONHECIMENTO DE EMBARQUE - BILL OF LADING - TRANSPORTE MARÍTIMO - SEGURO AÇÃO REGRESSIVA DE INDENIZAÇÃO E EXTINÇÃO DA AÇÃO SECUNDÁRIA - Recurso que objetiva discussão acerca das cláusulas limitativas de indenizacão que constam dos contratos celebrados entre a segurada e a $2 a$ co-ré e entre esta e a la co-ré - Vexata questio resolvida pela interpretação da cláusula 8.4 de fl. $68 v^{\circ}$ e cláusula 15 de fls. 247-248 - Em documento celebrado entre a importadora "Embraer" e a "Henderson Line", consta da cláusula 8.4, que a indenização do transporte da mercadoria está limitada a US\$500 dólares americanos, na hipótese de não haver declaração da carga e de seu valor - Igual previsão contida cláusula 15, trazido aos autos pela la co-ré - Documento traduzido por tradutor juramentado - Não obstante a solidariedade, nãa estão as co-rés, obrigadas a indenizar pelo pagamento de indenizacão superior àquele valor - Não socorre à autora ora apelánte o disposto o art. 10 do Decreto $n^{\circ}$ 19.473/30 - Disposição legal que não tem o condão de afastar cláusula limitativa da responsabilidade das co-rés - Embora a cláusula de não indenizar seja inoperante, nos contratos de transporte, conforme Súmula $n^{\circ} 161$, nãa há súmula ou precedente que obste a validade da cláusula de limitacão de responsabilidade - Apelo da autora improvido"

O recurso objetiva discussão acerca das cláusulas limitativas de indenização que constam dos contratos celebrados entre a Embraer e a 2 a core Henderson Line e entre esta e a la co-ré Aliança. A "vexata questio" é resolvida pela interpretação da cláusula 8.4 de fl. $68 v^{\circ}$ e cláusula 15 de fls. 247-248. 
No documento de fl. $68 v^{\circ}$, celebrado entre a importadora e a "Henderson Line", consta da cláusula 8.4, que a indenização do transporte da mercadoria está limitada a US\$500 dólares americanos.

Na cláusula 15 do documento citado acima, trazido aos autos pela la co-ré, vez que o documento juntado pela autora não contém o verso, traduzido por tradutor juramentado, consta, igualmente, que a indenização é limitada a US\$ dólares norte americanos, em caso de perda ou dano/à carga, exceto na hipótese de haver declaração da carga ou de seu valor.

Simples observação do documento, na sua partelfinal, em um dos campos, leva à conclusão de não houve declaração da carga e po valor, onde há, ainda, referência a cláusula 15, objeto de tradução do campo.

Para melhor compreensão, transcreve-se $\wedge^{\text {in }}$ yerbis", o objeto "Declared value (See clause 15): Não estão as co-rés, portanto, não obstante a solidariedade, responsáveis pelo pagamento de indenização superior àquele valor."

Não socorre à autora ora apelante o disposto o art. 1o do Decreto $n^{\circ} 19.473 / 30$.

"Conhecimento de Embarque - Bill of Lading - B/L - Decreto $n r .19 .473$ de 10/12/1930 - A matéria é regulada pelo Código Comercial (Lei no. 556 de 25.6.1850), que estipula o seguinte: "Art. 578 - Os conhecimentos serão assinados e entregues dentro de 24 (vinte e quatro) horas, depois de ultimada a carga, em resgate dos recibos provisórios; pena de serem responsáveis por todos os danos que resultarem do retardamento da viagem, tanto o capitão como os carregadores que houverem sido remissos na entrega dos mesmos conhecimentos."

Referida disposicão legal não tem o condão de afastar cláusula limitativa da responsabilidade das co-rés. Embora a cláusula de não indenizar seja inoperante, nos contratos de transporte, conforme Súmula $n^{\circ} 161$, não há súmula ou precedente que obste a validade da cláusula de limitação de responsabilidade.

A esse respeito, veja-se:

"VALIDADE DA CLÁUSULA DE LIMITAÇÃO DA RESPONSABILIDADE se o embarcador paga apenas o frete normal da mercadoria, correspondente ao valor declarado no conhecimento, sem indicar um valor maior como sendo o real valor da mercadoria transportada. STJ, AGA 27580, Min. Athos Carneiro, DJ 22.03.93, p. 4548"

"COMERCIAL. DIREITO MARÍTIMO. TRANSPORTE. CLÁUSULA LIMITATIVA DE RESPONSABILIDADE. VALIDADE. PRECEDENTE DA SEGUNDA SEÇÃO. RECURSO DESACOLHIDO. É válida a cláusula limitativa da responsabilidade de indenizar inserida em contrato de transporte marítimo. STJ - Resp. $n^{\circ} 36.706$ - SP, em 5.11.96"

"Após uma inicial divergência entre as turmas q je cohqpõem a Seção de Direito Privado deste Tribunal, foi firmado o entendimento no sentido de ser válida a cláusula limitativa da responsabilidade de indenizar no transporte marítimo, consoante se decidiu no REsp 39.082-SP^Jv1^3.95)l da 2 a Seção, relator para o acórdão o Sr. Min. Fontes de Alencar, assim então: Transporte

marítimo. Responsabilidade. Admissão de cláusula limitante da responsabilidade do transportador'.

"RESPONSABILIDADE. É valida a cláusula limitativa da responsabilidade de indenizar inserta em contrato de transporte maritimo. precedentes." (STJ, REsp 153.787/SP, Min. Barros Monteiro; DJ 06.04.1998 p. 136) 
"Transporte Maritimo. Responsabilidade. Admissão de cláusula limitante da responsabilidade do transportador." (STJ, REsp 39082, Min Nilson Naves, DJ 20.03.95, RSTJ v.69, p 353)

"Marítimo. Transporte marítimo. Cláusula limitativa de responsabilidade do transportador, cabível é a limitação da responsabilidade, se o embarcador apenas pagou o frete normal relativo à importância declarada no conhecimento de transporte quando lhe era possível indicar valor maior, com pagamento de maior frete. Não há que confundir tal cláusula com a de 'não indenizar' que a jurisprudência tem admitido como vedado pelo art. 1 o do Dec. $n^{\circ}$ 19.473/30. Entender-se diferentemente seria onerar injustificadamente, o transportador, posto que a fixação do frete se faz à base, inclusive, do valor da carga." (TFR, AC 45.006-SP, Min. Aldir Passarinho, RJTFR $n^{\circ}$ 55/128)

"No transporte marítimo tem validade a cláusula que limita a responsabilidade do transportador a 500 dólares por volume, que serviu de base para o cálculo do frete. Não se trata de cláusula de não indenizar, vedada pelo art. 1o do Dec. 19.473/30. Por essa cláusula não se elide a obrigação de o transportador entregar a mercadoria, ou indenizar o que nela se prevê, fixando-se apenas, o valor-base para a indenização, ficando ao embarcador a opção de declara-lo, pagando frete com uma sobretaxa, ou omitir o valor." (TARJ, AC 12.840-RJ, $\left.R T n^{\circ} 536 / 191\right)$

"CLÁUSULA LIMITATIVA DE RESPONSABILIDADE - Eficácia - Ação regressiva de seguradora - Procedência em parte - Apelação provida parcialmente. É válida a cláusula limitativa de responsabilidade de transportador quando estabelecida em caráter facultativo e com correspondência na redução de tarifas." (TJSP - Ap. Cív. 282.985 - Santos - j . 27.1279 - rei. José Cardinale).

"EMENTA: TRANSPORTE MARÍTIMO INTERNACIONAL. FURTO DE MERCADORIA. RESPONSABILIDADE OBJETIVA. ATO DE VISTORIA. LIMITAÇÃO DA RESPONSABILIDADE. Na ação de regresso o conhecimento de transporte não é documento essencial. A relação transportadorimportador é contratual, devendo ser regulada pelas disposições do Código Comercial. Conforme se infere do disposto nos artigos 102 e 103 do mencionado diploma, a responsabilidade do transportador é objetiva, somente podendo ser afastada mediante comprovação de que o dano tenha decorrido de vício da própria coisa, caso fortuito ou força maior. $O$ ato de vistoria aduaneira levada a efeito em 27 de maio de 2002 (fl.27), no Terminal do contêiner S/A em Rio Grande, constatando o extravio, é prova suficiente e idônea do dano. Válida a cláusula de limitação de responsabilidade, devendo corresponder ao valor constante no documento de transporte. Agravo retido e apelo da denunciada não providos. Apelo da ré provido em parte. TRIBUNAL DE JUSTIÇA DO RIO GRANDE DO SUL, 70009370792 - Apelação Cível, MARCELO CEZAR MULLER Julgamento: 18/01/2006 - Décima Primeira Câmara Cível."

"EMENTA: TRANSPORTE-MARITIMO. ACAO DE REEMBOLSO DO SEGURADOR. LIMITAÇÃO DA RESPONSABILIDADE DO TRANSPORTADOR EM US\$ 300,00 POR EMBALAGEM, DE ACORDO COM CLÁUSULA DO CONHECIMENTO MARÍTIMO ONDE NADA FOI INSERIDO QUANTO AO VALOR DA MERCADORIA. LICITUDE DA CLÁUSULA, QUE NÃO SE CONFUNDE COM A DE "NAO INDENIZAR". SUCUMBENCIA PARCIAL, DEVENDO OS HONORÁRIOS SEREM RECIPROCA E PROPORCIONALMENTE DISTRIBUÍDOS, BEM COMO, COMPENSADOS. 
Apelação CíveVNO 183005743, Quarta Câmara Cível, Tribunal de Alçada do RS, Relator: Mário /Augusto Ferrari, Julgado em 24/03/1983."

"TRANSPORTE MARITIMO CLÁUSULA RESPONSABILIDADE. RESULTANDO A (CLÁUSULA' L RESPONSABILIDADE EM TRANSPORTE MARÍTIMO INMTATIVA DE MIWIVA DE OPÇÃO PELO PAGAMENTO DE FRETE MENOR, NÃO HA DIZ CONTEXTO, NÃO ASSUME RELEVO O VALOR IRRISO STJ, RESP-67558/SP, Min. COSTA LEITE. TER DATA: 18/09/1995 $P G: 29962 . "$

"TRANSPORTE MARÍTIMO. SEGURO. CLÁUSULA DO CONHECIMENTO DE TRANSPORTE. AO SEGURADOR, SUBROGADO, NÃO E CONCEDIDO RECEBER QUANTIA SUPERIOR AQUELA DEVIDA PELO TRANSPORTADOR AO EMBARCADOR. DECISÃO QUE ADMITE A LIMITAÇÃO DA RESPONSABILIDADE DÁ À LEI INTERPRETAÇÃO PELO MENOS RAZOÁVEL. RECURSO EXTRAORDINÁRIO NÃO CONHECIDO STF RE 94985 / SP - SÃO PAULO, Min. CUNHA PEIXOTO, DJ 09-10-1981 PG-10058 EMENT VOL-01229-02 PG-00612 RTJ VOL-00104-01 PG-00357."

"SEGURO. TRANSPORTE DE MERCADORIA. CLÁUSULA LIMITATIVA. NÃO DISSENTE DA SÚMULA 161/STF, E MENOS DA SÚMULA 188/STF, ACÓRDÃO QUE LIMITOU A RESPONSABILIDADE DO TRANSPORTADOR AO VALOR CONVENCIONADO. A DIVERGENCIA COM PRINCIPIO SUMULADO HA DE SER EM RELAÇÃO AO QUE NELE ESTIVER DISPOSTO, E NÃO QUANTO AO QUE VIRTUALMENTE NELE SE CONTENHA. RECURSO ESPECIAL NÃO CONHECIDO. STJ, 3a Turma, Resp 1.691 / SP; Min. Nilson Naves; DJ 12.03.1990, p. 1704"

Não se acolhe, também, o apelo da autora, ficando mantida a brilhante sentença proferida pela magistrada Maria Cristina Cotrofe Biasi.',

(TJSP, Apelação Cível n ${ }^{\circ}$ 7.031.075-7, acórdão registrado sob o nº 01817681, Rel. Des. Salles Vieira, 24a Câmara de Direito Privado, j. 03/07/08)

Orlando Gomes se posiciona no sentido de reconhecer a validade da cláusula de limitação de responsabilidade tão somente nas situações em que a mesma não torne a importância a ser indenizada muito menor do que o dano real causado, uma vez que estaria muito próxima à cláusula de não indenizar, expressamente proibida, conforme prevê a súmula 161 do STF:

"Permitida é, entretanto, a cláusula de limitação da responsabilidade. Razão não há para proibir a inserção, no contrato, de cláusula penal que fixe o máximo da indenização e facilite a liquidação do dano. Nula será, todavia, se reduzir a importância tão insignificante que sua aceitação equivaleria à cláusula de não indenizar". 33

Os Tribunais, portanto, tem se posicionado majoritariamente no sentido da validade desta cláusula, cabendo destacar neste âmbito a

\footnotetext{
${ }^{33}$ GOMES, Orlando. Contratos. 26a ed. Rio de Janeiro, Forense, 2008. Pg. 379.
} 
expressa previsão legal constante nos artigos 17 e 32 da Lei 9.611/98, que dispõe sobre o transporte multimodal de cargas:

"Art. 17. A responsabilidade do Operador de Transporte Multimodal por prejuízos resultantes de perdas ou danos causados às mercadorias é limitada ao valor declarado pelo expedidor e consignado no Conhecimento de Transporte Multimodal, acrescido dos valores do frete e do seguro correspondentes.

(...) $\S 3^{\circ} \mathrm{Na}$ hipótese de o expedidor não declarar o valor das mercadorias, a responsabilidade do Operador de Transporte Multimodal ficará limitada ao valor que for estabelecido pelo Poder Executivo.

(...) Art. 32. O Poder Executivo regulamentará a cobertura securitária do transporte multimodal e expedirá os atos necessários a execução desta Lei .razo de cento e oitenta dias, contados da data de sua publicação.

$\S 1^{\circ}$ Enquanto não for regulamentado o disposto no $\S 3^{\circ}$ do art. 17 , será observado o limite de 666,67 DES (seiscentos e sessenta e seis Direitos Especiais de Saque e sessenta e sete centésimos) por volume ou unidade, ou de 2,00 DES (dois Direitos Especiais de Saque) por quilograma de peso bruto das mercadorias danificadas, avariadas ou extraviadas, prevalecendo a quantia que for maior.

$\S 2^{\circ}$ Para fins de aplicação dos limites estabelecidos no parágrafo anterior, levar-se-á em conta cada volume ou unidade de mercadoria declarada como conteúdo da unidade de carga".

Não obstante o entendimento acima exposto, cumpre destacar corrente contrária que se posiciona no sentido de negar validade à limitação da responsabilidade, sob o fundamento da incidência do Código de Defesa do Consumidor nas relações de transporte marítimo.

O presente trabalho não compartilha deste entendimento, com base na teoria finalista do conceito de consumidor, não restando configurada a relação de consumo nos contratos de transporte marítimo travados entre transportador e importador. Isso se dá pelo fato do transporte, objeto do contrato, ser um meio para a atividade econômica do importador, não sendo este o consumidor final do bem transportado e não restando configurada a sua vulnerabilidade ou hipossuficiência.

\subsection{N.V.O.C.C. - Non Vessel Operator Common Carrier}

Traduzindo-se literalmente, N.V.O.C.C. significa "carregador que não é operador de navio" ou "transportador não proprietário". Essa figura surgiu nos anos 80, principalmente por força da demanda dos pequenos embarcadores, uma vez que os mesmos tinham que pagar por um contêiner 
inteiro para carregar cargas de menor porte, ou ainda, tinham que aguardar o acúmulo de mercadorias.

Com a intensificação das relações comerciais, essa figura tornou-se cada vez mais importante, principalmente para os exportadores que trabalham com poucos volumes.

São empresas criadas pelos próprios armadores, com o intuito de consolidar cargas de pequeno porte. Estas empresas consolidadoras compram espaços nos navios para transportar seus contêineres, que, por sua vez, vão conter cargas de diversos clientes.

Esses agentes consolidadores ficam responsáveis pela estivagem e acondicionamento das cargas no contêiner, bem como por efetuar a descarga. A acomodação das cargas é um trabalho muito técnico, tendo em vista que cargas de diferentes naturezas serão acondicionadas dentro do mesmo contêiner. Por conta deste fato, as empresas N.V.O.C.C devem ter correspondentes nos portos de destino, para desembarque.

Esta modalidade ganhou muita força, verificando-se, inclusive, a contratação de N.V.O.C.C. por N.V.O.C.C. Diante da maior demanda por agentes consolidadores, as próprias empresas transportadoras acabaram por criar setores internos especializados em cargas fracionadas, acompanhando a atual realidade das relações comerciais, onde não apenas as grandes empresas têm necessidade de contratar o transporte marítimo. 


\section{CONCLUSÃO}

Encerra-se o presente trabalho com uma breve análise do que foi exposto, de forma a consolidar todo um raciocínio voltado para a compreensão do Direito Marítimo.

Através da exposição dos contratos de afretamento marítimo, podese perceber com clareza a divergência existente quanto à natureza jurídica deste instituto, defendendo-se, aqui, os mesmos não se confundem com os contratos de transporte. $\mathrm{Na}$ realidade, contrato de transporte é uma modalidade de utilização do navio, concluindo-se, portanto, que nem todo afretamento marítimo está voltado para o transporte de mercadorias.

Isso é evidenciado pela existência de navios de apoio, chamados de supply vessel. Nestes casos, há o afretamento de navios que servirão de apoio marítimo, por exemplo, para a exploração de petróleo e gás natural (apoio às plataformas), o que tem sido muito utilizado pela Petrobrás. Além dessas hipóteses, pode haver, ainda, o afretamento de rebocadores, para auxiliar nas manobras dos navios.

Numa análise mais profunda acerca dos contratos de transporte marítimo, restou claro que o Brasil continua muito defasado no que tange o aspecto jurídico do tema, tendo em vista que não recepcionou as principais convenções internacionais relacionadas, por adotar uma postura 'pró-carga', incompatível com os interesses dos transportadores marítimos.

A legislação interna, por sua vez, merece maior desenvolvimento e organização, uma vez que não regula de maneira completa a questão, estando, muitas vezes, limitada à mera delimitação de conceitos náuticos. Evidencia-se, portanto, a necessidade urgente de uma legislação mais completa e em maior consonância com o posicionamento internacional, de forma a incentivar o desenvolvimento da indústria naval brasileira e impulsionar as relações comerciais do país. 
Acredita-se que o objetivo do trabalho foi alcançado, ao esclarecer temas de suma importância para o desenvolvimento desta área. Não se pode mais ignorar a força do setor marítimo no país e a crescente demanda por profissionais especializados e aptos a tratarem das questões oriundas das relações comerciais marítimas. Por esta razão, faz-se aqui um apelo para que haja o maior desenvolvimento o estudo do Direito Marítimo nas universidades do país, de forma a impulsionar e consolidar um raciocínio marítimo. 


\section{REFERÊNCIAS BIBLIOGRÁFICAS}

GIBERTONI, Carla Adriana Comitre. Teoria e Prática do Direito Marítimo. Rio de Janeiro: Renovar, 2005. 590 p.

MARTINS, Eliane M Octaviano. Curso de Direito Marítimo Vol. II. Barueri, SP: Manole, 2008. 632 p.

LAMY, Eduardo de Avelar. Contrato de Transporte Marítimo Internacional: Competência e Legislação Aplicável. In: JÚNIOR, Osvaldo Agripinio de Castro. (Org.). Direito Marítimo Made in Brasil. São Paulo: Lex Editora, 2007. p. 97-119.

SILVÉRIO, Fernando; MAY, Otávia de Oliveira. A Cláusula de Eleição de Foro no Conhecimento de Transporte Marítimo (Bil of Lading). In: CASTRO JÚNIOR, Osvaldo Agripinio de. (Org.). Direito Marítimo Made in Brasil. São Paulo: Lex Editora, 2007. p. 121-164.

FERNANDES, Paulo Campos; LEITÃO, Walter de Sá. Responsabilidades no Transporte Marítimo. São Paulo: Aduaneiras, 2010. 250 p.

BASTOS, Nuno Manuel Castello-Branco. Da Disciplina do Contrato de Transporte Internacional de Mercadorias por Mar. Coimbra: Almedina, 2004. $451 \mathrm{p}$.

ARAUJO, Nadia de. Direito Internacional Privado: Teoria e Prática Brasileira. - 4.ed.atualizada e ampliada. Rio de Janeiro: Renovar, 2008. $642 \mathrm{p}$.

GOMES, Orlando. Contratos. $26^{\text {a }}$ ed. Rio de Janeiro: Forense, 2008. 627 p.

TEPEDINO, Gustavo, BARBOZA, Heloisa Helena e BODIN DE MORAES, Maria Celina. Código Civil Interpretado Conforme a Constituição da República - Vol. II. Rio de Janeiro: Renovar, 2006. 918 p. 
HEREZ, Santos. Introdução ao Direito Marítimo. Disponível em: www.boletimjuridico.com.br/doutrina/texto.asp?id=44. Inserido em 20/04/2003.

FLEURY, Paulo. A Infraestrutura E Os Desafios Logísticos Das Exportações Brasileiras. Em ww.ilos.com.br. Inserido em 10/04/2005. Gráfico desenvolvido pelo Ministério do Desenvolvimento, Indústria e Comércio Exterior.

STJ, Recurso Especial 251.438/RJ, Relatora Ministro Barros Monteiro, Brasília, 08 de agosto de 2000.

STJ, Embargos de Declaração nos Embargos de Declaração no Recurso Especial 1159796/PE, Relatora Ministra Nancy Andrighi, Brasília 25 de março de 2011.

STJ, Recurso Especial 46544/RS, Relator Ministro Salvio de Figueiredo Teixeira, Brasília 10 de maio de 1994.

STJ, Agravo Regimental no Agravo de Instrumento 27580, Ministro Athos Carneiro, Brasília 22 de março de 1993.

Tribunal de Justiça do Estado de São Paulo, Apelação Cível 7.031.075-7, Relator Desembargador Salles Vieira, São Paulo, 03 de julho de 2008. 


\section{Ocean Bill of Lading}

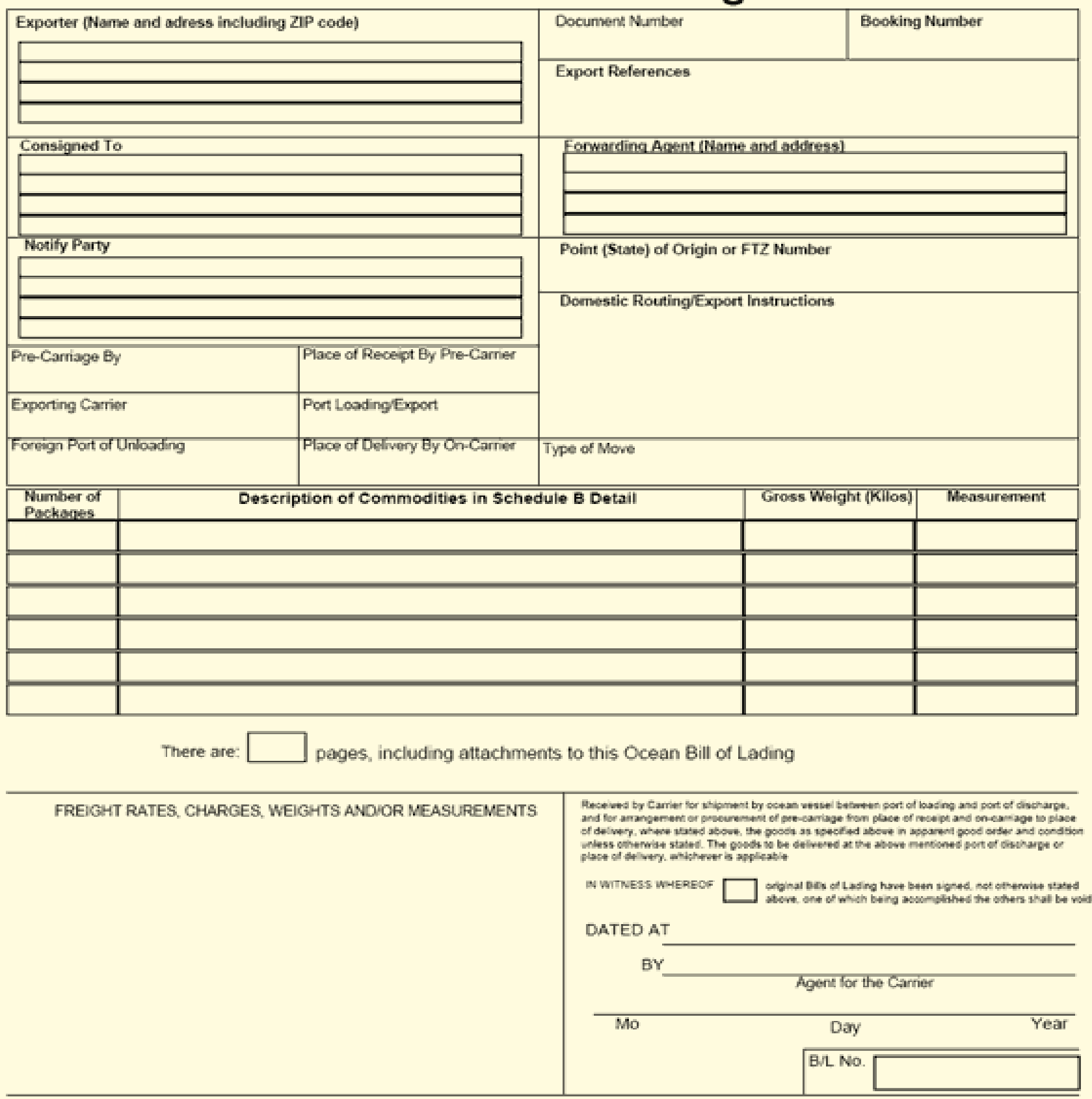

I certify that the above information is true and correct to the best of my knowledge

http://sharifpourcommerce.wordpress.com 